\title{
The material and cultural recovery of camels and camel husbandry among Sahrawi refugees of Western Sahara
}

\author{
Gabriele Volpato ${ }^{*}$ and Patricia Howard
}

\begin{abstract}
For nearly 1,500 years, Sahrawi nomads of Western Sahara respected the camel; camels were essential to life in the desert environment, constituting both the main means of production and exchange and the keystone of Sahrawi cultural identity. The capacity to adapt to drought is crucial for the resilience of nomadic populations, which are particularly susceptible to its repeated occurrence. Knowledge of coping strategies is transmitted and embedded deeply within nomads' cultural institutions. In 1975, the Moroccan army occupied the Sahrawi's traditional nomadic territory, decimating camel herds and forcing most Sahrawi into refugee camps in Algeria where the Sahrawi became wholly dependent on foreign aid for their sustenance. However, with the signing of a ceasefire agreement in the early 1990s, the Sahrawi recovered part of their nomadic territory and the right to move within it, while at the same time, new flows of capital entered the camps. Refugees began to recover camel husbandry as a livelihood strategy and the camel re-emerged as a potent symbol as refugees and the Polisario Front (the Sahrawi's political representative) struggle to assert their newfound national identity, regain access to all of their traditional territory and reaffirm their shared nomadic cultural heritage.
\end{abstract}

Keywords: Camel pastoralism; Refugee camps; Forced displacement; Herd losses; Cultural identity; Livelihood strategies; Agency

\section{Introduction}

For the past several decades, scholars and development organizations have increasingly focused on nomadic populations in part because, across the globe, their cultures and socio-ecological systems are threatened by the creation of political boundaries, forced sedentarization and resource depletion and in part because they have become aware of the complexity and efficacy of such systems in relation to resource management in harsh environmental conditions (Keenan 2003; Gauthier-Pilters 1961; Chatty 2005). Research has also been conducted on the keystone role of the camel among these populations (Köhler-Rollefson 2003), on their traditional ethnobiological and ethnoveterinary knowledge (Volpato et al. 2013a; Mohamed and Hussein 1996; Abbas et al. 2002) and on the human-camel relations from an anthropological perspective (Catley 2006).

\footnotetext{
* Correspondence: gabriele.volpato@wur.nl

Department of Social Sciences, Wageningen University, Hollandseweg 1, Wageningen 6706 KN, The Netherlands
}

Studies of herd loss and recovery among contemporary nomadic populations with drought and protracted conflict are central to pastoralist studies (Boneh 1984; Khalif and Oba 2013; Mezhoud and Oxby 2013). Such studies are situated within an anthropological literature that understands sedentarization as a recurrent phenomenon within nomadic societies (Salzman 1980; Adano and Witsenburg 2005; Blench 2001). The case of the Sahrawi can be contextualized precisely within this literature. Over the past 1,500 years, when their camel herds were largely depleted or severely weakened by drought or military assault, Sahrawi nomads could no longer appropriate desert resources and were forced to retreat to the periphery of their nomadic territories where they sought other means to survive outside of the desert, i.e. in oases, in coastal towns (where fishing was possible) or in agricultural settlements (Caro Baroja 1955). Destitute nomads relocated to other areas either near wealthy camps or settlements (offering services to them, seeking assimilation and surviving on public slaughter and milk redistribution), 
or emigrating to the agricultural villages of the Oued Draa and Oued Nun or, less commonly, to the oases of central Mauritania. After herds were decimated by recurrent droughts, with the return of the rains, nomads began to repopulate the desert with their surviving herds or animals received in mniha (camel loans) ${ }^{\mathrm{a}}$. Nomads who had lost all of their camels engaged in trade or other activities to acquire camels and initiate their real and metaphorical travel back towards the 'centre of the desert'.

In the 20th century, the strategies that the Sahrawi deploy to confront the Moroccan threat to their nomadic way of life and recover camels after dispossession while in exile in essence represent an extension or adaptation of their traditional mix of strategies for dealing with drought and military assault. In 1975, for the first time in their history, the Sahrawi were forced to confront an enemy with vastly superior military power and, in the process, lost all access to their traditional pastoral territories; most lost their mobility, herds and alternative means of livelihood. Most fled Morocco's military assaults, taking refuge in camps where they became utterly dependent upon foreign aid for the duration of the prolonged (16 years) guerrilla war that the Sahrawi waged against the Moroccan Army. The Sahrawi experienced greater social, cultural and political change living as refugees in a protracted situation. This time, the particular confluence of factors that permit refugees to proactively recover herds and reoccupy the desert, and the means by which they have adapted to these new conditions, signals profound changes in the economic, technical, social and cultural relations of camel husbandry in the Western Sahara and in the Sahrawi's social formation.

The study of pastoralists who have lost their herds and become refugees is directly relevant not only to the understanding of contemporary pastoralist societies that are confronted with herd loss and physical displacement, but as well to the study of refugees more generally and of their attempts to recover pre-conflict/pre-disaster livelihoods. Dispossessed pastoralists generally reconstitute herds only in the long term, which may be compared with the time required for refugees living in protracted situations to regain their subsistence strategies and cultural identity (Khalif and Oba 2013; McCabe 1987). In refugee camps, people's individual and collective agency - their capacity and actions to 'transcend the dictates of their immediate environment and...shape their life circumstances and the course of their lives' (Bandura 2006. p. 165) - are severely constrained; they are deprived of access to most resources, confront limited opportunities (e.g. for mobility or education) and high levels of risk (e.g. looting, conflict, further displacement) (Jacobsen 2005). When people become refugees, their traditional productive activities and the associated knowledge, cultural practices and artefacts may be lost forever. However, once in camps, as conditions permit, refugees struggle to reassert their agency, develop productive activities and revitalize the associated knowledge and practices. In the process, these are adapted to new environmental, social, cultural, political and economic contexts (Golooba-Mutebi and Tollman 2004; Jacobsen 2002; Horst 2006a).

Because refugees lose everything with forced displacement into camps, recovery must occur from scratch. Studies about such autochthonous recovery processes (e.g. not purposively facilitated by aid agencies or governments) and of refugees' individual and collective agency can help to formulate policies that promote refugees' material and cultural well-being. The international community can support refugee's own efforts to regain access to the means of subsistence (e.g. livestock, land) by facilitating the economic means and necessary institutional conditions (e.g. mobility, security, legal entitlements) (Meyer 2006). As the case study presented here shows, aid can be instrumental to the recovery process in that it represents a safety net for refugees who have no access to other resources, removes the burden of procuring basic provisions for survival while capitals are rebuilt and provides seed capital for refugees' own pursuits (Fiddian-Qasmiyeh 2011; Lentz et al. 2005). As Harvey and Lind (2005, p. 26) argue for Turkana pastoralists of Kenya, 'Food aid can provide the incentive for pastoralists to hold onto animals, and thereby contribute to the livelihood recovery process after an emergency.'

As refugees' worldviews, beliefs, values, cognition (including knowledge) and social relations are strongly rooted in their pre-exile worlds, their recovery strategies are informed by pre-exile modes of subsistence, social relations, cultural values and adaptive strategies. Especially among former pastoral and nomadic refugees, and within the constraints presented by the structure of camps and access to pastoral territories, refugees' agency is directed towards the recovery of livestock husbandry, including a return, as far as possible, to nomadism or transhumance. At the same time, however, refugees become integrated within trans-regional and transnational processes through political struggles, foreign aid, emigration and informal and formal markets for wage labour and other commodities. Pastoralism and nomadism are also being transformed through economic globalization (Chatty 2005; Bollig et al. 2013; Gertel and Le Heron 2011), and refugee herd recovery is thus accompanied by change in the material and cultural use and management of herds related to these larger transformation processes. The individual and collective struggles to recover pre-exile modes of subsistence and livestock husbandry are motivated not only by the desire to improve the material conditions of life and gain greater autonomy; pre-exile modes of subsistence have great continuing cultural significance that refugees and their political representatives may re-appropriate 
and adapt to promote and strengthen identity that underlie claims to national sovereignty and territory.

In this paper, we address refugees' agency towards recovering camel husbandry, the conditions that permitted this process to occur and come to fruition, as well as the transformations in camel husbandry that are emerging, focusing on the case of Sahrawi refugees living in camps near Tindouf, in western Algeria ${ }^{\mathrm{b}}$. Historically, camels were central to the production and reproduction of Sahrawi nomadic society, providing staple food, means of transport and warfare, means of exchange and the basis of power and prestige. With war and displacement, most of the Sahrawi who fled lost their camel herds, became refugees settled in camps and depended on international food aid for survival. Although several authors reported the recovery of livestock husbandry among Sahrawi refugees at the turn of the millennium (Bhatia 2001; Caratini 2007b; Mundy 2007; de Juan Canales 2010; Herz 2013), little attention has been given to the trajectory pastoralism took beginning with war and sedentarization in refugee camps or to Sahrawi refugees' agentic actions to recover camel husbandry. Indeed, the Sahrawi are seldom referred to in modern literature on pastoralism; for example, they are not mentioned in Homewood's (2008) recent book on the ecology of African pastoralist societies and are generally absent from edited books on pastoralism (Chatty 2005; Bollig et al. 2013). We argue that, at the beginning of the 1990s, a co-occurrence of factors (renewed access to territory, military demobilization and increased access to cash through pensions, remittances and aid) created conditions for the redevelopment of productive activities, trade and the emergence of an informal economy in the camps themselves. In continuity with their nomadic past, some refugees gained access to camels and resumed camel husbandry. These processes revitalized camel-associated traditional knowledge and the material and cultural bonds between refugees and their homeland (Volpato and Puri 2014). The camel was re-appropriated as a symbol of a shared nomadic heritage and cultural identity, and camel products and associated knowledge and practices were deployed in the Polisario's and refugees' nationalistic discourse vis-à-vis Morocco as well as to reinforce national and ethnic unity. As discussed at the end of the paper, the fact that Morocco has also attempted to incorporate the camel into Moroccan national identity shows that there is a continuing struggle between the two parties to claim and monopolize Sahrawi nomadic heritage.

After presenting the current context in the 'Background' section, in this paper, we: (1) describe how the Sahrawi became refugees and lost their herds; (2) discuss the historical, social, economic, cultural and ecological processes that facilitated the recovery of camel husbandry among Sahrawi refugees; (3) characterize contemporary camel husbandry and its importance within Sahrawi refugee camps; (4) discuss the changes that occurred in camel husbandry in the process and (5) analyse the contemporary role of camels in Sahrawi cultural and political identity.

\section{Background}

The Sahrawi, literally 'people from the desert', are pastoralists who traditionally inhabited coastal areas of northwestern Africa including Western Sahara, northern Mauritania and part of southwestern Algeria. The Sahrawi were essentially nomadic, pasturing camels, goats and sheep in the low-lying plains of Western Sahara and relying for food on livestock products as well as dates, sugar, cereals and legumes that were bartered for livestock in markets on the periphery of their nomadic areas (Caro Baroja 1955). In 1975, the Moroccan army occupied Western Sahara, forcing about 70,000 Sahrawi to flee and settle in camps established in neighbouring Algeria (San Martin 2010). A 16-year war ensued between Morocco and the Sahrawi's armed political organization, the Polisario Front (1975 to 1991). Throughout this period, the Sahrawi were excluded from most of their former Western Sahara territory by means of a wall erected by the Moroccans (known as the berm) that cuts through Western Sahara in a north-south direction. Today, about 165,000 Sahrawi live in four refugee camps located on the Hamada desert plateau near Tindouf in Algeria (Figures 1 and 2).

Refugees live in tents and mud brick huts and confront continuous problems with water, food and energy supplies. Food, shelter and other basic commodities are provided by the European Union, certain bilateral development programmes, UN agencies, the Algerian government and several solidarity groups (San Martin 2010). Over the years, refugees have attempted to improve the quality of life in the camps, developing an informal economy where they market a variety of basic consumer products as well as food. They are involved in wage labour (e.g. as butchers, mechanics, construction workers, etc.) and trade between the camps and Mali, Mauritania, Algeria and Spain (Dedenis 2005; Herz 2013). Some have migrated abroad and send remittances home. Economic activity has greatly increased since a United Nations-sponsored ceasefire agreement was signed with Morocco in 1991, which resulted in the demobilization of Polisario troops who moved into the camps and began to re-engage in livestock husbandry, seasonal nomadism and trade.

With the ceasefire agreement, the Polisario Front also assumed political control over the Eastern, inland areas of the Western Sahara (Bhatia 2001), the so-called liberated territories (approximately $20 \%$ of the Western Sahara) ${ }^{\mathrm{c}}$ while the remaining 'occupied territories' are under the Moroccan Government's administrative authority. Pastoral areas within the liberated territories are important to the refugees' struggle to maintain or recover traditional 


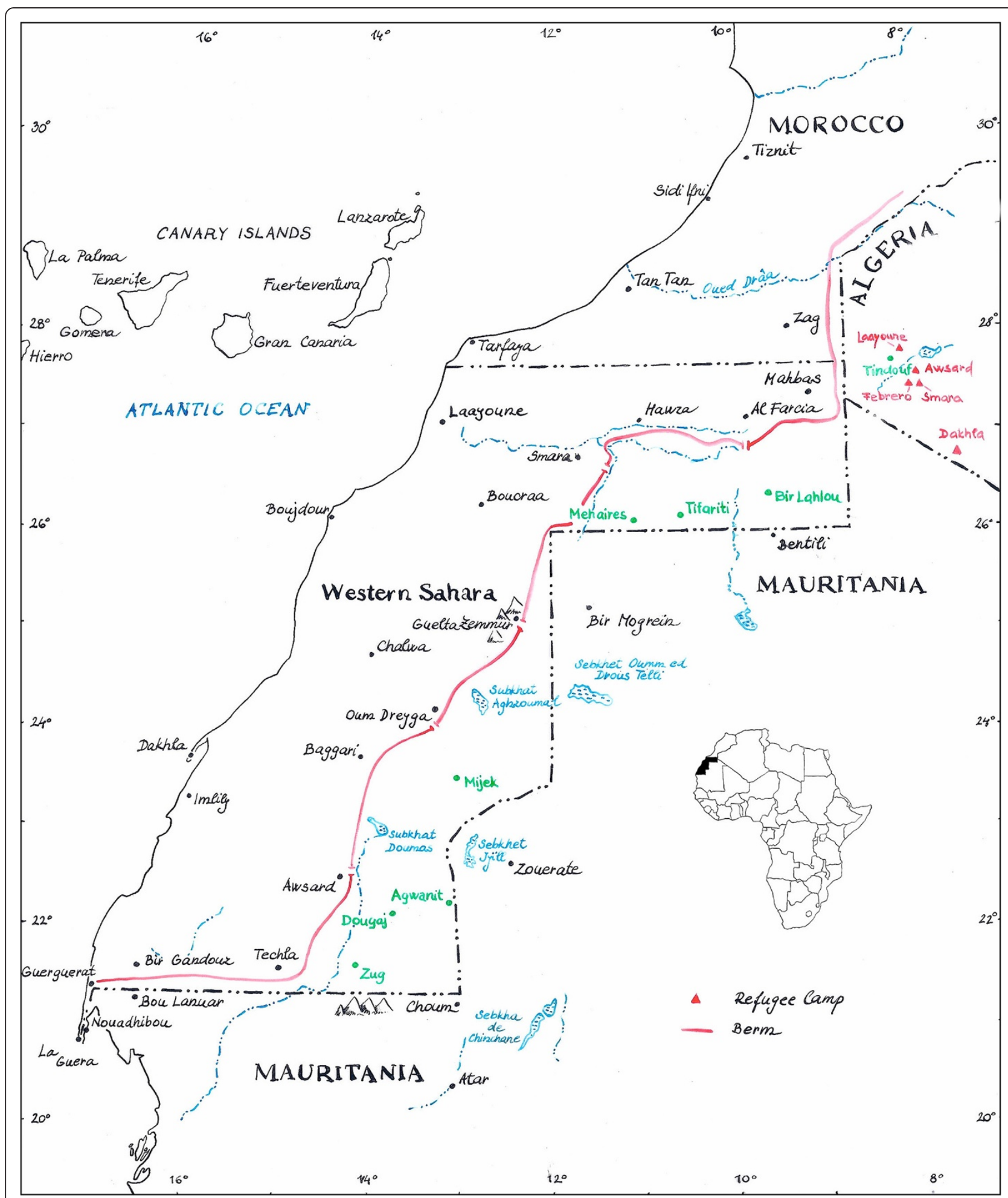

Figure 1 Map of Western Sahara with refugee camps and the liberated territories ( $P$. Kourková).

cultural and social practices, from livestock husbandry to medicinal plant use (Volpato et al. 2012), as well as to generate income, e.g. through the sale of desert truffles (Volpato et al. 2013b). Some 20 to 30,000 Sahrawi who remained nomadic throughout the war by moving with their herds to safe areas in neighbouring Mauritania and Mali also reoccupied these territories after 1991, herding their livestock and using the refugee camps and Zouérat 


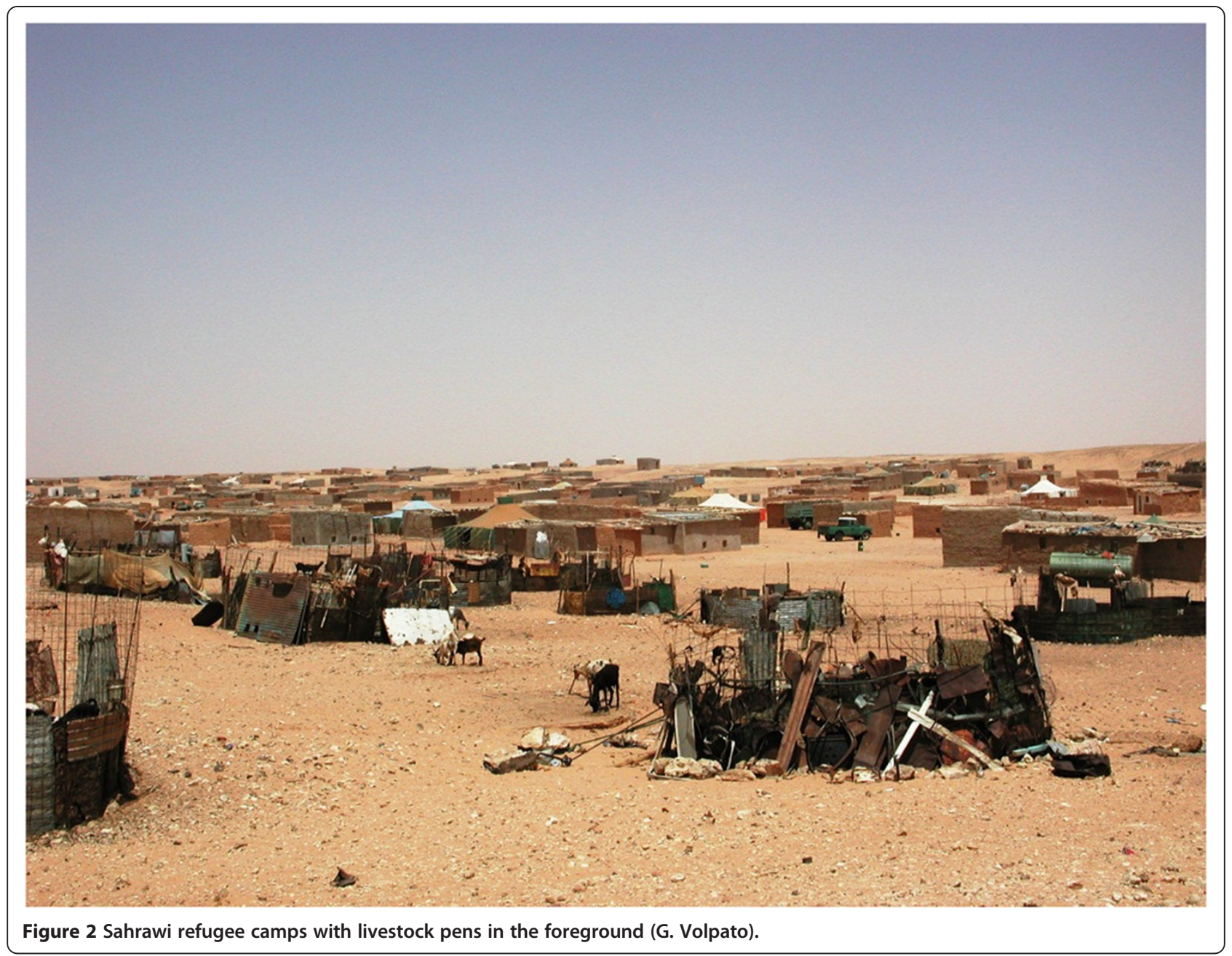

(in Mauritania) as their main commercial hubs. Today, camel husbandry is practiced in the liberated territories as well as, to a lesser extent, in the areas surrounding the refugee camps. About 2,000 camels are raised in the camps, whereas some 40,000 are raised in the liberated territories (DNV-RASD 2007). Furthermore, the Polisario own and tend some 27,000 camels in the liberated territories, where soldiers or paid labourers act as shepherds (Broglia and Volpato 2008). In refugee camps, camel owners supplement natural forage with fodder purchased in Tindouf. In contrast, nomads (full-time and seasonal) practice extensive camel husbandry in the liberated territories, that is, husbandry that is highly dependent on pasture areas and mobility for herd production and reproduction.

Whereas, throughout their history, tribal and camp leaders (re)distributed subsistence goods and means of production in camels and organized the defense of camps, camels and territory; today, the Polisario provides and distributes aid and defends and controls the refugee camps and the liberated territories. Although refugees are highly dependent on food aid, the Polisario produces a small part of the refugees' food supply. An important part of this production comes from Polisario livestock herds ${ }^{\mathrm{d}}$ which directly supply refugees with fresh camel milk and she-camels loaned to disadvantaged and poorer refugees, the elderly, former combatants and their families, and gift young or male camels for slaughter, e.g. for weddings. The Polisario also allocate milk-producing camels to workers in public places such as schools and hospitals. Polisario herds also supply livestock and their products for important rituals connected with social or political events. Livestock husbandry is one of the refugees' few endogenous activities developed and recovered without any consistent attention or funding from donors and development organizations. In the past decade, camels have also been the subject of international cooperation projects promoting health and nutrition through the supply of camel milk and meat (Mundubat 2007). These projects are carried out and funded by non-governmental organizations (NGOs) under the Polisario's initiative and largely mirror the forms of support that the Polisario provides with its herds. 
The recovery of camel husbandry is ongoing in the refugee camps of the Hamada and in the liberated territories where refugees travel and nomads live. The Hamada is a barren desert plateau known historically as the 'Devil's Garden' because rainfall is scarce and edaphic conditions are poor, which explains why it has very poor forage resources, few trees, no halophytic plants and few annuals. Across the liberated territories, the climate is also arid and continental, with summer daytime temperatures surpassing $50^{\circ} \mathrm{C}$, while winter temperatures drop to zero at night. In the territories, rain generally occurs from the end of the summer through autumn. Average annual rainfall is 30 to $50 \mathrm{~mm}$; however, rains are highly irregular both within and between years, and droughts are recurrent. But, in comparison with the Hamada, the liberated territories and especially the northern area, called Zemmur, are richer in biodiversity and forage plants. After the rains, they display a savannah-like environment dominated by Acacia trees, and flowering prairies may appear in flat gravel areas.

\section{War, Sahrawi nomads and their herds}

Morocco's occupation of the Western Sahara and the ensuing war led to the decimation of camel herds and a drastic reduction in the number of Sahrawi that remained nomadic. In 1974, on the eve of the invasion, there were some 75,000 Sahrawi, only $40 \%$ to $45 \%$ of whom were nomads (Pazzanita 2006a, b; Censo-74 1974) ${ }^{\mathrm{e}}$ tending about 50,000 camels, as well as numerous goats and sheep (Mercer 1976b). Prolonged droughts in the 1960s and 1970s led many Sahrawi to sedentarize in the expanding urban areas in the periphery. The number of nomads and camels had been declining in Western Sahara since at least the 1950s, but this decline assumed almost epic proportions with occupation and war and might have led to the collapse, if not of this entire population, certainly of their way of life.

Although figures are far from certain, it is estimated that about 55,000 Sahrawi (or about $70 \%$ of the population) fled to the refugee camps (Mercer 1976a), about half of whom were nomads. The Moroccan air force bombarded temporary refugee camps in Western Saharan territory (at Oum Dreiga, Mahbes, Amgala and Guelta Zemmour) with napalm, white phosphorus and cluster bombs, causing Western Sahara towns to depopulate at the same time that Tindouf refugee camps swelled (Hultman 1977) . Such panic was produced among most of the Sahrawi population that they tried to escape at any cost (San Martin 2005), leaving their homes and belongings, livestock, jobs, in many cases, ceding their moveable property (herds, jeeps and trucks) to the Polisario forces that organized and carried out both the flight and the guerrilla war that ensued to recover their territory (Lippert 1992; Brazier 1997). The establishment of refugee camps behind the Algerian military outpost of Tindouf in Algerian territory meant that refugees were safe from bombings and that Polisario forces had a place to train former tribesmen and organize guerrilla war (Martin 1976).

Nomads, whose resilience and herds had already been weakened and reduced by droughts and colonialism (Capot-Rey 1962; Mercer 1976b), had to quickly decide whether to try to maintain their herds or liquidate them and flee to safety with other refugees. Apart from the bombings and well poisonings, they risked having their herds confiscated and being forced to sedentarize, having their mobility curtailed and dealing with possible lack of pasture within and across the borders of a country engulfed in war (Arkell 1991; Gaudio 1993). During the war, herds were bombed, abandoned, slaughtered and sold off by different agents (Pazzanita 2006a, b). The Moroccan offensive against camel herds was also meant to cut off the Polisario guerrilla's food supplies and logistical support. As a consequence, the large majority of Sahrawi nomads disbanded and joined the refugee camps soon after the invasion or within the next few years. Many attempted to sell their herds before fleeing in spite of the fact that prices had plummeted and cash buyers were difficult to find. At times, fleeing nomads abandoned herds in their customary nomadic territory in the (misplaced) hope that the animals could be recovered when stability had returned. Those who managed to reach refugee camps in Algeria with their herds often had to sell them (e.g. to local Algerian nomads) cheaply because they could not be fed and managed in the camps. Probably one of the most significant phenomena within this process was the Polisario's nationalization of camel herds. Some nomads turned their herds over to the Polisario rather than attempting to sell them, and the Polisario also appropriated some of the abandoned herds ${ }^{g}$ and sought to manage 'national' camel herds within the nomadic territories that they could access or defend. These herds supported soldiers in the field (e.g. with meat and milk, since motor vehicles rather than camels were used for transport) and at times provided fresh meat for refugees.

Still, several thousand nomads did not lose their herds or flee to the camps. A report from the early 1980s (Camacho 1987) suggests that about 10,000 Sahrawi remained nomadic by moving to safe areas (e.g. West Algeria, Mauritania, northern Mali), making use of cross-border (or transnational) social relations based on tribal membership and solidarity with the Polisario. In the new system of social relations that emerged with the war, the Polisario became a supra-tribal power able to fight for the recovery of territory, represent the Sahrawi people as a whole internationally and provide refugees with the necessary means of consumption through political and humanitarian support. Nomads provided the Polisario militia with milk and meat from camels and small livestock and in turn were protected from 
Moroccan incursions. Those nomads that survived slowly moved back to the liberated territories after the ceasefire agreement of 1991.

Refugees suffered tremendously from the war: when fleeing through the desert, many lost children to starvation and spouses and parents succumbed to bombings, napalm attacks and extra-judicial executions (Lippert 1992; Hernández 2013). Old people, women and children suffered from severe malnutrition, lack of clean water, diseases and epidemic infections (Mercer 1976a). In this context, it was impossible for tens of thousands of sedentarized refugees to rely on their own labour and resources for survival (Wilson 2012). Providing the population with aid in the form of food, shelter, fuel and clothing was essential (Lippert 1992). Those first years saw a collectivist war-economy develop based on international food aid managed and delivered to refugees by the Polisario and state (Sahrawi Arab Democratic Republic (SADR)) institutions ${ }^{\text {h }}$ which established a national administration in exile in the refugee camps (San Martin 2005, 2010). Refugees depended on the Polisario, which assumed and transformed many of the functions played by traditional nomadic Sahrawi camps and tribes (Farah 2008). Irrespective of previous social differences (e.g. of wealth or caste), refugees all became equal in that they lost their livelihoods and property and became dependent on aid; livestock, the former basis of wealth, were nowhere to be seen. The few refugees who managed to bring livestock to the camps had to confine them in a single public pen (Wilson 2012), effectively collectivizing their scarce resources. As Herz (2013), p. 12 argued, 'much of the nomadic culture was discarded, as life in the camps did not lend itself to the keeping of large camel herds.' Private trade was prohibited in the camps, and money was not used as currency. All of this began to change with the ceasefire agreement of 1991, which led to social relaxation in the camps, with greater freedom of movement of people and goods, the emergence of a private market sector and its acceptance by Polisario authorities and new opportunities for refugees to pursue individual and family livelihood strategies. This permitted Sahrawi refugees to exercise their agency in order to recover camel husbandry, as seen below.

\section{Refugees' recovery of camel husbandry}

The recovery of camel husbandry among refugees was triggered by different but interacting economic, political, ecological, cultural and social drivers. The form this took was strongly informed by the past and also strongly influenced by the nature of these drivers and of the changing context. With the material and political change stemming from the ceasefire agreement of 1991 and, given the lack of alternative livelihood pathways in the desert environment, many refugees pursued camel husbandry as a path towards food security and livelihood diversification. The ceasefire agreement granted refugees access to part of their former nomadic territory (the liberated territories) and its grazing resources. Military operations ceased and Polisario soldiers were demobilized, which meant that many men with experience in camel husbandry returned to the camps and attempted to continue their activities. Sahrawi nomads also moved back to the liberated territories with camel herds that could be sold or loaned to refugees. Now firmly under the military control of the Polisario, safety and security in the camps and the liberated territories allowed refugees to invest and travel without threat to their persons and belongings and to renew mobility by means of jeeps, which allowed them to travel to markets (e.g. Tindouf) and to their former nomadic territories. Livestock and equipment purchases were facilitated by access to cash through, among other sources, Spanish civil pensions, donations and remittances. This also stimulated the development of productive activities and trade, leading to the growth of an informal economy in the camps, as well as widespread extra-camp trade and other economic and social interactions. Refugees emigrated (e.g. to Spain) and sent remittances or repatriated earnings while establishing transnational networks through diaspora. Camel and small livestock husbandry emerged as one of the very few means to sustainably exploit the resources of the Western Sahara, facilitated by the favourable rains of the past 10 to 15 years. Camel husbandry provides refugees with their traditional staple foods - fresh milk and, to a lesser extent, meat, in a context where, as in the past, agriculture is barely possible and hunting and gathering resources are very limited. Livestock husbandry traditionally provided resources for barter and now provides access to cash. Below, this process is addressed in more detail, starting with the means by which refugees gained access to camels in the camps.

\section{Access to capital and the development of an informal economy in refugee camps}

Soon after Polisario soldiers were demobilized and joined refugees in the camps, they began to engage in all sorts of informal private commercial and productive activity, boosting economic life. Up to that moment, mainly women undertook the limited economic activities in the camps as they attempted to supplement consumption; former soldiers slowly refocused household activities towards production for trade and commerce. A similar transformation occurred in relation to livestock: traditionally, women managed small livestock production for own consumption and they re-initiated this during the war, whereas camel husbandry and commercial livestock production can be traced in most instances to demobilized fighters (Mundy 2007).

A large number of refugees gained access to cash through Spanish pensions, remittances, funds obtained through the programme Vacaciones en Paz (Holidays in Peace), formal and informal microcredit including loans from NGOs and other refugees, and trade (de Juan Canales 2010; Herz 
2013). In 1988, the Spanish Government authorized pension payments to about 5,000 Sahrawi who had worked for the colonial Government of the Spanish Sahara (e.g. as public workers and troops). These pensions (400 to $500 €$ per month) were paid retroactively as a lump sum, so many refugees received a substantial amount, which permitted them to invest in livestock and four-wheel drive vehicles as well as provide loans or credit to others, etc. Thus, cash began to circulate in the camps and incipient commercial activity arose with Tindouf and towns in Mauritania. Since the mid-1990s, a relatively steady number of Sahrawi refugees have emigrated to work in Spain (with smaller numbers going to other countries) to support their families in the camps, and emigration was often bankrolled by Spanish pensions. Remittances (e.g. from Spain, the Canary Islands, Algeria and Mauritania) also provided ready cash. A more limited flow of remittances and other forms of assistance enters refugee camps from Sahrawi living in that part of Western Sahara that is under Moroccan administration.

Another important source of cash comes from Spanish families who host between 7,000 to 10,000 Sahrawi children per summer in Spain through a programme known as Vacaciones en Paz (Crivello et al. 2005, 2006; de Juan Canales 2009). When returning to the camps, children bring gifts for themselves (e.g. clothes, toys) and their families (e.g. solar panels, appliances and money, on average $300 €$ per year) provided by the host families or local solidarity associations (Morando 2006; Crivello et al. 2006). Some host families collect money to send to the children's families in the camps, thus greatly contributing to refugees' income and to the emergence of a cash economy (Crivello et al. 2006). It is estimated that this injects between $500,000 €$ and $1,000,000 €$ into the camps each year (Mundy 2007).

Since the 1990s, refugees have also benefitted from small grants and microcredit programmes offered by NGOs to initiate small enterprises (Elizondo et al. 2008), which has boosted productive activities and self-reliance among refugees (Cavaglieri 2005). In some cases, microcredit has directly funded camel purchases to initiate milk production (López Belloso and Mendia Azkue 2009). Besides formal microcredit, funds are provided informally by Sahrawi refugees through credit, loans and delayed payments in market transactions, particularly to relatives and acquaintances, increasing the number of refugees with access to cash. Cash empowered refugees through forms of redistribution, as is also found with other refugee populations (Koser and Al-Ali 2001; Horst 2006b). On a smaller scale, refugees with no access to cash may sell part of the aid that they receive to purchase other food (e.g. fresh camel meat and milk) or non-food products (e.g. coal) (Corbet 2008), thus allowing them to participate in the camps' market economy.
The cash entering the camps permitted petty commerce, commodity production and a market economy to develop in the camps (Shelley 2010; Herz 2013) involving an everincreasing number of refugees. Together, the potential to engage in long-term investment and commercial activities, and the proliferation of informal markets both within the camps and further afield, not only provided certain preconditions for the resurgence of camel husbandry but as well ensured that the social and technical relations entailed in newfound pastoralism would be substantially different from the nomadic past.

\section{The requirements of camel husbandry recovery}

Sahrawi refugees have attempted to recover livestock ever since they first settled in refugee camps. It has been shown in other contexts that one strategy used to restock is to diversify economically, as income gained in other sectors can be channeled into pastoralism (Horowitz and Little 1987). Among the Sahrawi, the recovery began with small livestock (goats and sheep) and it was only after the mid1990s that this evolved into camel husbandry. Today, a large majority of refugee households maintain small livestock in pens around the camps (Herz 2013); compared with camels, small livestock are more economically accessible, have higher reproduction rates and fewer nutritional requirements, are more easily sold and have a more convenient size for own consumption; hence, pastoralists commonly begin with small livestock and only upscale to camel husbandry if and when conditions permit (Dahl 1979; Mace and Houston 1989). During the war, refugees generally lacked means to access camels (raids were banned and refugees had insufficient capital to purchase camels) and also lacked pastures in areas surrounding the camps. Accumulating the cash to purchase a camel (about 400 to $600 €)$ is not easy, and camel husbandry in the camps is even more onerous since further initial investments are required for pens, water tanks and fodder, while high risks of loss are entailed due to unfavourable husbandry conditions (Broglia and Volpato 2008). The material requirements of camel husbandry included access to camels, to fodder and pastures, to associated social networks (e.g. for labour, herd management, product distribution, etc.) and also access to the requisite camel-related knowledge.

While the recovery of camel husbandry is still rather limited in terms of the numbers of refugees and camels involved, it is highly relevant both materially and culturally. While most refugee households own some goats and sheep, very few (1\% to $5 \%$ ) own camels, totaling only a few thousand camels per camp. For almost all such refugees, camel husbandry is a productive activity that complements food aid and meets social and cultural expectations related to both camels and their products. Camel husbandry continues to be constrained by refugees' lack of capital and by the unfavourable environmental conditions of the camps. 


\section{Diversity of access to camels}

With the ceasefire agreement of 1991, access to the liberated territories and the demobilization of soldiers, on the one hand, and the increased inflow of cash into the camps, on the other, began to stimulate the recovery of camel husbandry, which was further sustained by the potential to market meat and milk in the camps. Camel purchases arose, in order of importance, in the liberated territories, Mauritania, Mali, Algeria and Niger, and were sometimes embedded in elaborate trade involving the Sahrawi diaspora. A number of cases demonstrate both the fact that the strategies refugees use to access camels may be quite complex, involving a 'chain' of activities and investments, as well as the diverse motives for accessing camels. Camels are gifted and inherited, as is the case with a 15-year-old boy who received a gift of two she-camels from his father. They are also purchased from savings - a 50-year-old refugee living in the Aaiun camp initiated a commercial camel herd by purchasing camels in Mauritania with cash obtained from his Spanish pension. Some are obtained through barter: one refugee emigrated to Spain, bought two cars and then exchanged them in the camps for eight camels, which are pastured in the liberated territories using a hired shepherd and which provide milk and other use values for his family when the rains come and they move to the liberated territories to live seasonally as nomads. One refugee migrated to Spain where he worked for a year in construction and, with the money he saved, bought a second-hand truck. He travelled with the truck via boat to Nouadhibou (Mauritania), and then overland to Azawad (in northern Mali), where he exchanged the truck for about 40 camels. He then travelled back to the camps and hired shepherds to bring the camels to him. Once there, the camels were sold to local butchers for a net profit. A woman who obtained remittances from her brother working in Spain bought a milk-producing camel to provide fresh milk for her widowed father. A couple with three children bought two she-camels with money that two of the children received from their hosts in Spain. Collective agency (requiring shared aims and coordination of interdependent plans of action; Bandura 2006) may also be involved in camel purchases usually, but not always, among kin; in at least one case, four neighbouring (non-kin) households in the camp of Aaiun purchased a milk-producing camel, sharing the costs as well as the milk produced.

Other refugees obtained camels through non-monetary social relations (e.g. from nomadic or refugee kin or acquaintances with herds) as gifts (in which camel ownership is transferred) or, more often, loans (in which ownership is not transferred and camels are used for milk production). Reciprocity involving camels and camel products was very important to the maintenance of social cohesion among Sahrawi nomads and occurred mainly through kinship in accordance with tribal organization.
Contemporary redistributive mechanisms serve functions that are similar to those strategies (e.g. mniha - the act of lending milk-producing camels and their calves to fellow tribesmen, an institution embedded in nomadic Sahrawi society) that redistributed camel surpluses through a wider population, permitting destitute nomads to reconstitute herds or survive drought or raids. Similar institutions are present in different pastoral populations throughout the world (Faye 2009) and, in many cases, their demise has increased pastoralist vulnerability to droughts and other stresses (McCabe 1990) or, conversely, they have become increasingly important to the survival and functioning of these communities (Ziker 2006).

Once Sahrawi refugees have managed to renew access to camels, these traditional institutions have been revitalized and adapted: camels and camel milk began to be redistributed through gifts and loans, permitting access to a larger refugee population. One refugee camel owner, for example, gave three 2-year-old camels as gifts, one to a family of acquaintances, another to a young man who was helping him in construction work and a third to a cousin who gave the name of the camel owner to her newborn child. These camels may be then kept for milk production or, especially if young, slaughtered to provide meat for a wedding or baptism. However, the number of refugees receiving camels as gifts is rather limited. Loans (and delayed credit) are more widespread. Mniha plays an important role in the reemergence of camel husbandry among refugees, where refugee and nomadic relatives from the liberated territories, Mauritania, and even from the Moroccan-controlled territories loan the camels, or camels may be loaned within the camps, as when a 'milk project' owner (see below) loaned a she-camel to the widow of one of his former workers.

\section{Typology of camel husbandry in the refugee camps}

We have addressed how refugees managed, through economic and social means, to access camels, arguing that this access was made possible by the inflow of cash into the camps and the re-activation of social networks. Renewed access to camels, however, did not give rise to the re-emergence of traditional extensive camel husbandry among refugees, but rather led to different forms of settled or partially settled husbandry. Refugee camel pastoralists are socially differentiated, which is reflected in herd size, social-economic relations and camel management practices. Broadly, three main forms of camel husbandry can be distinguished in the camps: (1) those who produce milk for own consumption (from two to a handful of shecamels); (2) small-scale commercial milk producers (from 10 to 30 camels), who sell milk after providing for own consumption and gifts; and (3) large-scale commercially oriented meat and milk producers (30 to 100 camels). In all cases, milk and meat are sold exclusively within the camps. 
Refugees in the first category keep their camels under nograzing conditions in a pen close to the household or on the camp's periphery (Figure 3). Camels are fed food scraps, hay and fodder and are watered from wells or potable water pipes. Refugees are strongly motivated to maintain camels for milk production (Figure 4) both because it is an essential staple and marker of cultural identity and because of beliefs that camel milk has health-giving and nutritional properties, especially for the ill and the elderly. These refugees consume or give away all milk produced. Milk is gifted to relatives or neighbours or given in exchange for labour (such as for camel milking). For example, soon after receiving his Spanish pension, one 60-year-old refugee and former nomad and his family moved to the periphery of the Smara camp, built a livestock pen and bought two shecamels with their calves. Although he lost his camels after a year, he re-invested and is now very proud of his four shecamels and three calves, which provide milk for his and one of his married son's family.

Owners of medium-sized herds maintain most camels in free-grazing conditions in the liberated territories or in the Hamada of Tindouf, while some are kept in the camp to produce milk for own consumption, distribution and, at times, for sale. For example, one herder kept five milkproducing camels in the camp where besides providing for own consumption, a small fraction of the surplus milk produced was given away, while most was sold to cover the costs of fodder and water. This group includes many demobilized soldiers who maintain a 'traditional' approach to camel husbandry: they sell relatively small quantities of milk (e.g. 10 to $20 \mathrm{~L}$ per day), keeping some for themselves and for relatives and neighbours, while periodically distributing milk for free on a larger scale (some give all the milk produced on Fridays). The herd that is maintained in freegrazing conditions is usually loosely guarded if grazed around the camps or tended by nomadic relatives if grazed in the liberated territories. Such herds are used to support nomadic relatives, obtain cash from the sale of males and as a form of savings.

The third group consists of those who manage private enterprises of variable size (up to 100 camels) primarily devoted to sales of fresh camel milk (up to hundreds of litres per day) and/or meat in the camps. Their organization is more formal compared with smaller-scale producers and is based on the use of wage labour, with small quantities of milk destined for own consumption and gifted to the workforce. Milking is done by hand; milk is unpasteurized and is packaged in plastic bottles. It is taken to the camps by jeep and sold directly to refugees in local markets or indirectly via shops selling prepared food or groceries in the camps. Productive and non-productive she-camels are managed separately; milk-producing camels are kept on the periphery of the camps and fed mainly cut fodder, whereas the rest are kept under free-grazing conditions in the liberated territories or northern Mauritania. These enterprises are sometimes called 'milk production cooperatives' since some are the result of the joint investment of various refugees who then share the earnings. Milk projects have increased in number over the past decade due to increased camel milk demand. The profits obtained have generated substantial

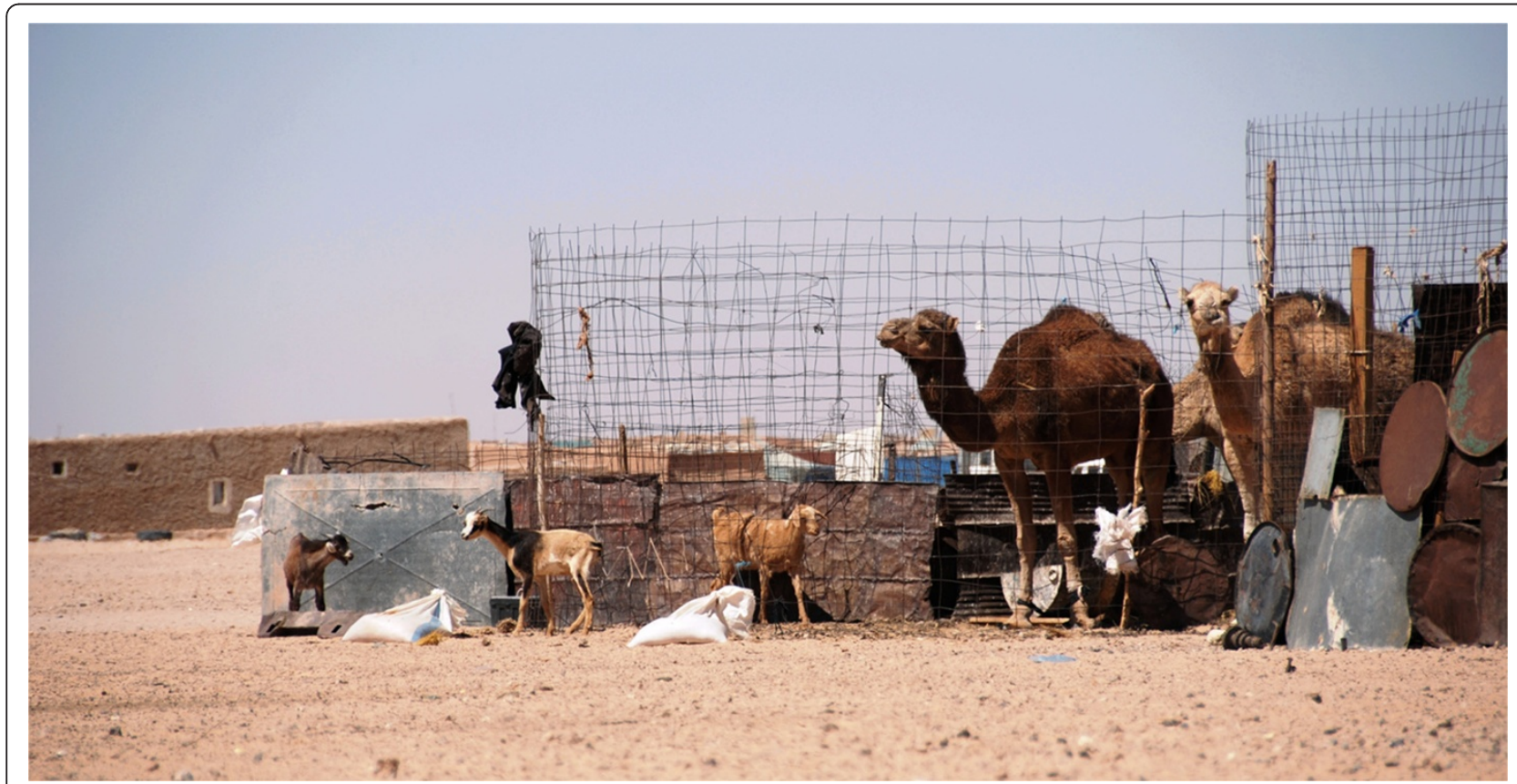

Figure 3 Camels in a pen (G. Volpato). 


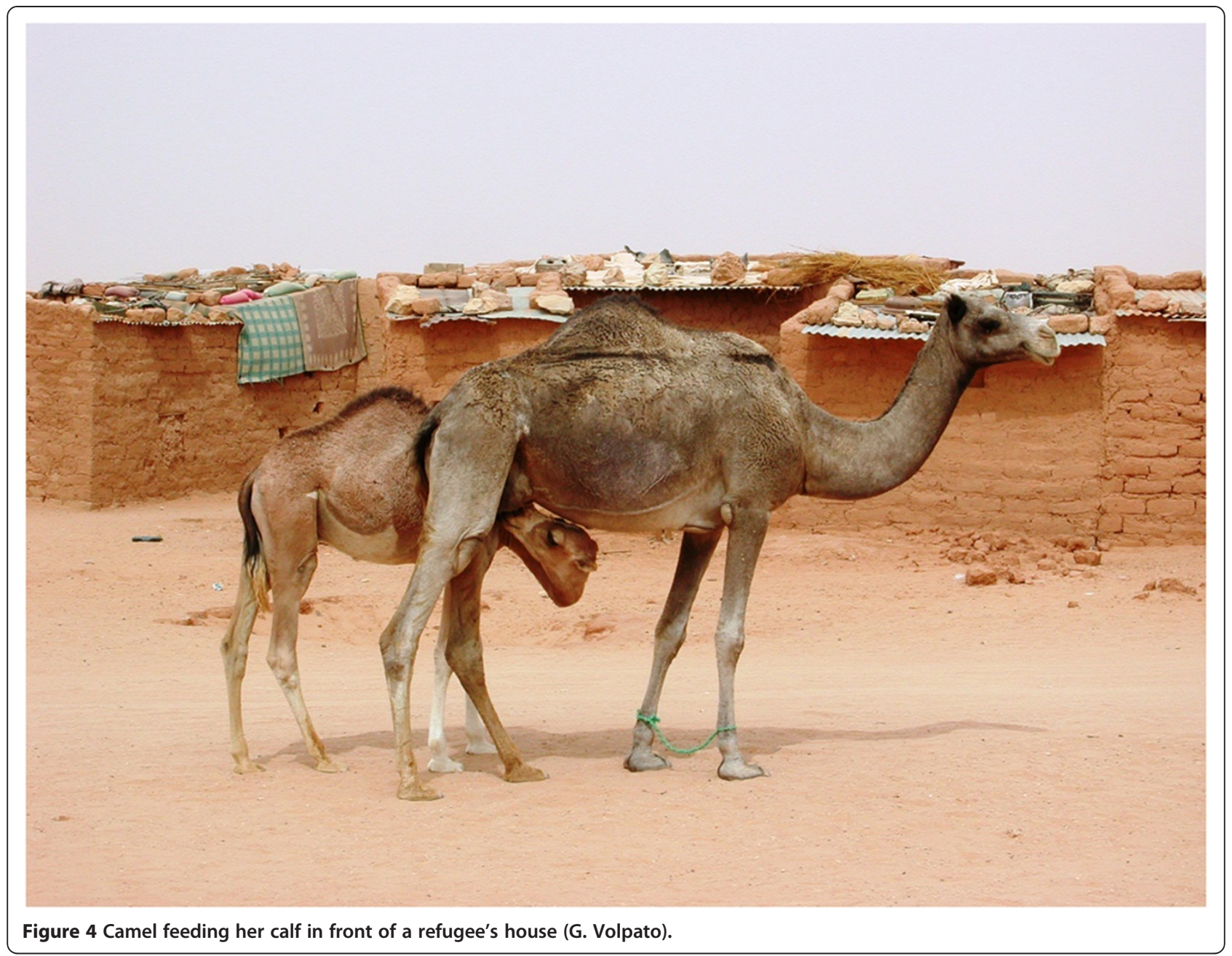

personal wealth for some. The main constraint to initiating a milk project is the lack of financial resources required to invest in a large milk herd; the funds used to date were obtained through remittances, Spanish pensions and/or earnings from other commercial activities.

\section{Access to the liberated territories}

The Sahrawi's traditional pastoral territory was almost inaccessible to pastoralists while engulfed in war from 1975 to 1991 but, since then, the 'liberated' areas have been key to the re-emergence of camel husbandry and camel-related practices among refugees as they provide grazing resources for refugees' and nomads' herds, as well as a place for nomads to live and refugees to move in seasonal or 'holiday' nomadism. Refugees' use of the liberated territories and northern Mauritania (where the Sahrawi have free informal access) for pasturing herds is informed by an economic rationale related to the emergent markets for livestock and livestock products in the refugee camps, as camel herds spend fallow or fattening periods in free-grazing conditions in these regions. This is especially the case for refugees with larger herds: in milk enterprises, fallow she-camels are grazed in the liberated territories as long as forage plants are available (after rains) to 'keep them healthy with good forage' and save the cost of feeding them in the camps on cut fodder. In meat enterprises, especially after rains, refugee herders use the liberated territories to fatten camels and small livestock before selling or slaughtering them in the camps.

Besides enjoying milk and meat in the camps, some refugees move seasonally with their livestock to the liberated territories where they consume these products. Some move to fatten livestock, purchasing small livestock and camels before heading for the badiya. One family bought about 300 goats and sheep and 40 camels which were sold upon return to the camps; in at least two cases, this system was embedded in the camel trade destined to supply meat to the camps - camels are bought in Mauritania or Mali, brought to the liberated territories where she-camels provide milk for seasonal nomadic refugees, males are fattened and, at the end of the period, sold to butchers in the camps. 
Besides this economic rationale, seasonal nomadism is informed by many refugees' desire to enjoy a nomadic life in the badiya (Volpato and Rossi 2014). Each autumn and/ or winter, depending on the location of rains, thousands of refugees move to the badiya (especially its northern area) together with their livestock, tents, food stocks and various tools and other personal items, 'to graze camel herds and get away from the camps' (Mundy 2007, p. 295). Dedenis (2005, pp. 86-87) and Caratini (2007a, pp. 192-193) report that trips to the badiya may take the form of a 'holiday' (i.e. periods based on consumption rather than production), where refugees plan get-togethers with their nomadic relatives or celebrate important events (e.g. childbirths, weddings). Such seasonal nomadic strategies are encountered among other pastoral populations. In Ethiopia, for example, the refugee camps in neighbouring Somaliland were incorporated into seasonal nomadic movements so that nomads could rely on the camps' food networks during the dry season when pasture was difficult to find and milk was scarce, and refugees in turn enjoyed livestock products during the rainy season (Ryle 1992). Boulay (2004) also described the phenomenon among former nomadic inhabitants of Nouakchott and other Mauritanian cities of a 'return to the badiya' after the rainy season for a milk and meat 'cure'.

\section{Access to knowledge}

The knowledge a population holds about a mode of subsistence or productive activity is developed and transmitted across generations of engagement with a local environment and is commonly termed 'traditional,' 'local' or 'indigenous' knowledge (Ellen et al. 2013; Vandebroek et al. 2011). As with other pastoral populations across the world, including the neighbouring Tuareg (Antoine-Moussiaux et al. 2007), over the centuries, Sahrawi pastoralists have accumulated, shared and transmitted knowledge of camel husbandry in the desert environment of Western Sahara, including ethnobotanical knowledge about camel forage (Volpato and Puri 2014), ethnoveterinary knowledge required to diagnose and treat camel diseases (Volpato et al. 2013a) and ethnoecological knowledge about weather and rainfall patterns, soils, the location of wells and water points, distances and trajectories for transiting the desert and many other types of knowledge. With forced displacement, herd loss and sedentarization in refugee camps, knowledge transmission was disrupted. Younger people's disengagement with camels and the desert environment led to a lack of both the need and opportunities to learn. Decades of restrictions on access to nomadic territories meant there were no encounters with the learning environments in which camel and desert-related knowledge was transmitted, and knowledge acquisition and transmission became dormant (Volpato and Puri 2014). A shift in values associated with formal education, emigration and exposure to mass media and to development schemes further alienated younger refugees from camel husbandry and the associated knowledge and cultural heritage, which some have even come to regard in negative terms.

With the resurgence of camel husbandry, which also involves young refugees who have no previous experience, many have struggled to revitalize the associated knowledge. The sources of this knowledge, principally older refugees and those who remained nomads, are involved in both vertical and horizontal knowledge transmission paths (Volpato and Puri 2014). Recipients are not only those refugees who re-engage in camel husbandry but also political organizations and NGOs that support refugees. For the first two decades after exile, the SADR government and international organizations focused on guaranteeing the supply of basic items required for refugees' survival, and the conservation of traditional Sahrawi knowledge was not an issue of public concern. However, with the recovery of part of the Sahrawi's nomadic territory, the growing reconstitution of herds and flocks, and a string of years with favourable climatic conditions, camel-associated knowledge regained importance in the public sphere. Caratini (2000, p. 445), for example, says that 'the Polisario Front have reconstituted a camel stock [...] and it realized that the loss of know-how in regard to livestock husbandry (based on the knowledge of the desert and of livestock needs) might represent a handicap both in the eventuality of a resumption of the war and given the perspective of peace.' In light of this, after the ceasefire agreement was signed, the Polisario involved its soldiers in a learning pastoral life' exercise involving nomadic shepherds (Caratini 2000). The Polisario's revalorization of camel-related knowledge also entails the promotion of camel husbandry among younger generations and refugees as a symbol of cultural identity. For example, since 1992, the Festival de la Cultura $y$ de las Artes Populares (Festival of Culture and Popular Arts) is held annually in Dakhla refugee camp, in which 'members of the older generations are actively engaged in teaching the youth a culture and traditional lifestyle that young people cannot find in school books' (SPS 2005). Besides being crucial to camel husbandry, the recovery of camel-associated knowledge and values is functional to Polisario and Sahrawi refugees' assertions of political independence and rights to their territory as discussed below.

\section{The emergence of peri-urban, commoditized camel husbandry}

Technically and economically, the camel husbandry system developing in and around the refugee camps is quite similar to the peri-urban milk and meat camel husbandry systems that have developed around Saharan towns over the past few decades (Chaibou and Faye 2005; Faye et al. 2003). In fact, across arid and semi-arid areas of Africa, camel husbandry represents a viable productive pathway and has 
progressively become commoditized through marketing of camels and camel products in peri-urban husbandry systems. The transformation of pastoral nomads into petty commodity or capitalist producers, and of subsistence pastoral production into commodity production, has been occurring throughout Africa to various degrees and at various scales with increasing integration of camel milk and meat markets at regional and national scales (Herren 1992; Nori et al. 2006).

Recovery among Sahrawi refugees has thus entailed very substantial changes in environmental, technical and social relations of production and exchange compared with the nomadic past, and in several ways reflects refugees' dependence on, and engagement with, a transnational political economy. Their dependence on extra-territorial aid and income, their exposure to formal education and to formal and informal markets in the camps and abroad, their settlement in and reliance on the camps with limited access to their former territories and the fact that not all refugees are able to access the capital required to restock camel herds have all brought about such change. Below, we address three main aspects of this change, namely (1) the technological intensification of camel husbandry, (2) the commodification of camel products and (3) the establishment of new social relations around camel husbandry. We then address cultural expectations and resistance associated with these changes.

\section{Changes in camel management and technological intensification}

As the relationship with the nomadic territory disintegrated, camel husbandry in the camps came to rely far less on the biological resources of the desert and far more on imported capital and fodder. While nomadic camel husbandry depends on mobility and extensive free-grazing as main strategies to feed camel herds, refugees are sedentarized and lack grazing resources, so camel husbandry in the camps is mainly based on purchased fodder as well as flour, straw and barley grain. The economic viability of camel husbandry around the camps depends on the cost of feed and other inputs costs and access to the means to cover them. The need to purchase fodder places an economic burden on camel owners and often forces them to generate revenues from production to pay for feed; fodder is either purchased with the same sources of cash used to access camels or with revenue from milk sales.

The intensification of camel production among refugees does not occur through breeding or the use of tools or machines to substitute human labour (and thus reduce the costs of production). Rather, intensification, as understood here and as described for peri-urban camel systems in other parts of the world (Faye et al. 2003), refers to the substitution of extensive land use (grazing on wild forage plants) with intensive input use - essentially, camels are confined in a smaller spaces and live from purchased fodder, trucked in water supplies and modern veterinary medicines. Different authors have noted a more general tendency in Saharan camel husbandry towards reduced mobility and grazing intake and increased consumption of fodder and supplementary feeds (Michel et al. 1997; Faye et al. 2003). Throughout the last century or so, the use of supplementary livestock feeds has increased worldwide in part as a result of the increasing availability of cheap agro-industrial by-products and mechanized transport systems capable of delivering them in bulk (Blench 2001).

In most cases, fodder is purchased in Tindouf. Travel and trade, including for fodder purchase, are facilitated by the diffusion of vehicle transport that, since the 1990s, greatly facilitated refugees' mobility (Dedenis 2005). After the war, jeeps and trucks have superseded camels as a means of transport. Camels now provide transport only on a limited scale and only among nomads, but few nomadic households regularly move to new grazing areas with their belongings packed on camels. Although, as Bulliet (1975) described so brilliantly, for 2,000 years, the camel managed to displace the wheel in North Africa and the Middle East, in the 20th century, the wheel, now coupled with the internal combustion engine, took its revenge, and the use of camels for transport went into steep decline. The widespread use of jeeps and trucks in desert environments has had profound impacts on camel pastoralists' lifestyle (Chatty 1980, 1986). Owning a 'land rover' is a principle ambition among Sahrawi refugees and one of the first commodities they acquire when they have sufficient cash is a motor vehicle. These facilitate trade and inter-camp transit, serving as taxis and transporting goods to and from Tindouf, the liberated territories and Mauritania. People ride camels in the camps only during SADR political or ritual celebrations when mounted camel parades are performed to demonstrate the Sahrawi's nomadic origins (Figure 5). The camel has become a symbol of Sahrawi cultural identity in public and political rituals and demonstrations as, for example, in 1997, when James Baker, the former UN mediator of the Polisario-Morocco conflict, visited the camps and again in 2006, in Tifariti, for the 30th anniversary of the SADR's foundation.

The diffusion of motor vehicles has also changed camel management. Most successful refugee camel owners own a jeep or truck. Especially market-oriented camel herders use other complementary technologies such as tanker trucks, GPS and satellite phones. Trucks make it easier to supplement camels' diets with harvested wild plants, hay and fodder. The historical constraints related to water provision for camels are addressed by developing new wells, mechanization (pumps) and tanker trucks that bring water to the herds, which obviates the need to move herds to water. There is generally increased reliance on owned or rented tanker trucks both among refugees and nomadic 


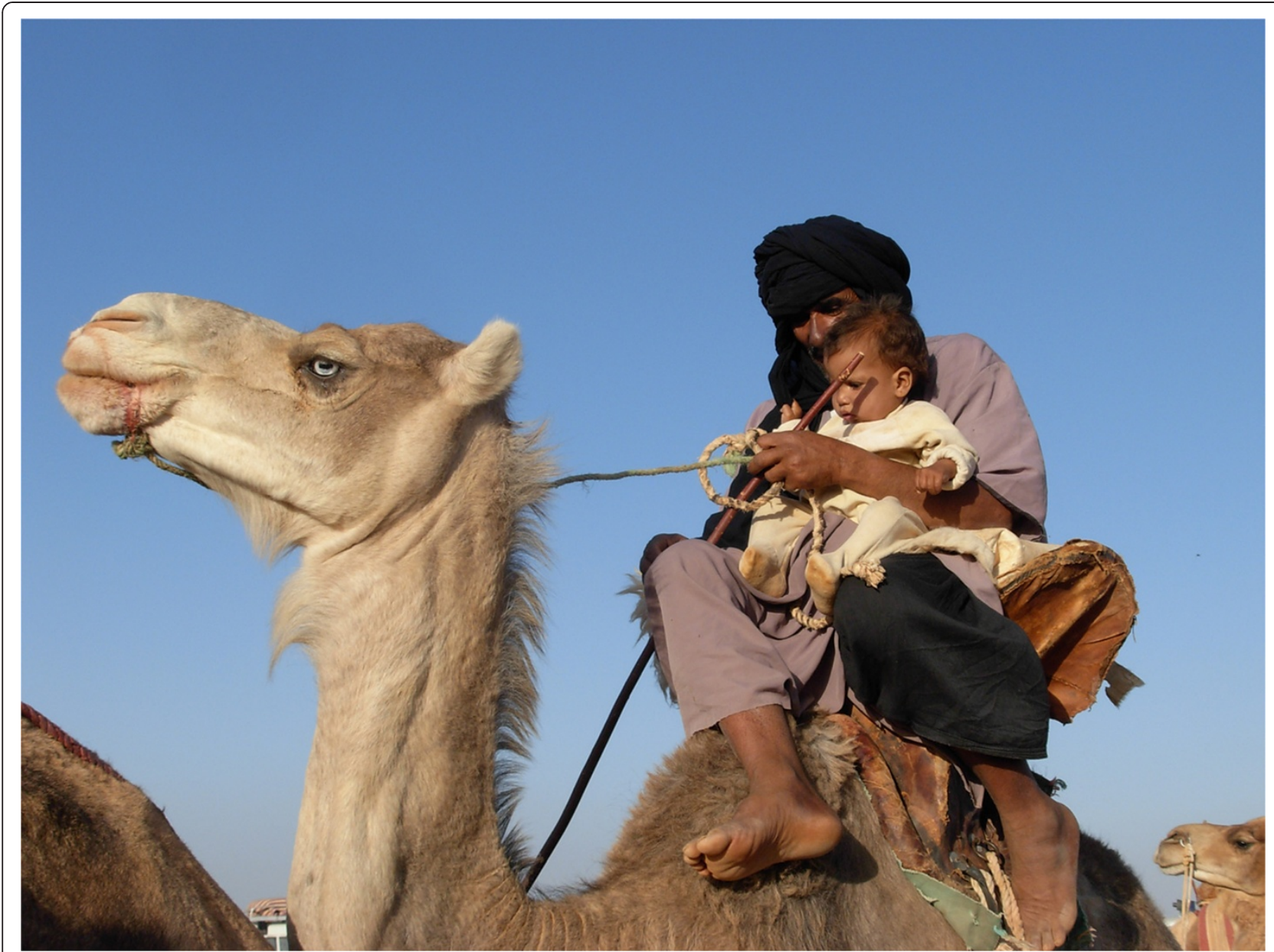

Figure 5 Camel riding during a political celebration in Rabouni refugee camp (G. Volpato).

herders, particularly for larger, market-oriented herds. Herds can exploit grazing resources in the liberated territories that would otherwise be too distant from water points, whereas in the camps, it permits large herds to be maintained on the periphery where water is deposited in large tanks.

\section{Camel milk commodification}

Although historically, the Sahrawi traded surplus camels, an unprecedented process of commodification of camels and camel products is occurring among refugees. Camels are no longer bartered for food and other essentials but are sold for profit; meat is sold in butcher shops and milk, which it was formerly taboo to sell, is subject to widespread trade and high consumer demand. As trade gave rise to an informal economy in the camps, camel milk has become at least partly commoditized, as have other natural products that were previously not subject to monetary exchange, such as plant medicines and desert truffles (Volpato et al. 2013b).
Studies investigating Sahrawi refugees' dietary intake confirm that camel milk is widely consumed (Henjum et al. 2010; Grewal 2011). Refugees source camel milk in three ways: (1) own production, which is very limited due to the small number of refugees who own or maintain camels; (2) social mechanisms of redistribution in which refugee camel owners, the Polisario Front and certain international NGOs maintain milk-producing camels in and around the camps and provide refugees with fresh milk through family, social and/or political networks; and (3) purchase in camp shops and directly from refugee producers, which accounts for the majority of the milk consumed in the camps. About half of the refugee camel owners surveyed by the first author $(n=44)$ sell camel milk. Nomads $(n=30)$, however, do not sell camel milk but rather, as in the past, redistribute it through kinship and other networks, to neighbouring households that have no milk-producing camels and to labourers that manage herds as well as to their families.

The commodification of camel milk in Sahrawi refugee camps reflects trends reported in urban markets across 
Saharan Africa (Faye et al. 2003), from the Western Sahara under Moroccan administration (Michel et al. 1997) and Mauritania (Abeiderrahmane 2005) to Kenya (Noor et al. 2013) and Somalia (Farah et al. 2007); the same trends are found, for example, in Saudi Arabia (Faye et al. 2014). Commodification occurs through two possible paths: through the penetration of capitalist relations of production, and/or as a necessary adaptation to husbandry in sedentary conditions. The second particularly applies to Sahrawi refugees; camels had to be fed purchased fodder. Sahrawi refugees were forced to incorporate fixed and variable capital to substitute resources otherwise obtained for free in their traditional territories. In order to obtain the capital needed to maintain camels in the camps, refugees began to sell at least part of their milk. In a few but farreaching cases, this led some refugees to develop large herds and seek profits. At the same time, these changes have been met with resistance on the part of some refugees with a nomadic background who challenge changes that have occurred such as the commodification of camel milk, which has fundamentally altered social relations and challenged traditional values and beliefs. Indeed, the Sahrawi have maintained a more traditional approach in nomadic conditions (e.g. in the liberated territories), where the redistribution of camel milk still constitutes the basis of the nomadic community, giving credibility to the idea that it is need, rather than greed, that has led to milk commodification.

\section{Social relations around camel husbandry}

Over the past 50 years, Sahrawi social relations and political organization have undergone no less than a revolution. Major social and political change commenced with colonialism and war and culminated with exile and the creation of a Sahrawi nation-state, the SADR (see footnote $h$ ). Historically, the Sahrawi were organized politically in tribes, where several inhabited the traditional territories (e.g. Reguibat, Izarguien, Oulad Delim, Oulad Tidrarin, etc.; see Briggs 1960; Pazzanita 2006a, b) in a segmentary system that further subdivided each tribe into branches based on extended families and other kinship ties (Hart 1998; Caro Baroja 1955). Tribal relations determined access to pasture where each tribe controlled a customary nomadic area. Decision-making institutions and networks of mutual support functioned along tribal lines and especially within branches (Caratini 1989). The tribes of Western Sahara continuously interacted through trade, war, raids, agreements of mutual access to each other's customary areas (e.g. with drought), alliances, tribute payments, etc. Although this political organization was disrupted with colonialism, it was in the mid-1970s that it was completely overturned by events: with exile and the establishment of the camps, the Polisario banned tribes and reorganized the Sahrawi under a newly declared nation-state in which each refugee became a citizen of the SADR and pledged allegiance to the Polisario, which controls and grants refugees access to the liberated territories and manages food aid (Wilson 2012; Caratini 2003). While kinship continues to have considerable importance among contemporary Sahrawi, tribal affiliation gave way to Polisario allegiance, and the Polisario Front de facto assumed the functions previously assumed by tribes and extended this to incorporate other functions of the modern nation-state, e.g. international political representation. Among Sahrawi refugees, social relations have been established and/or reformulated around camel husbandry on the basis of kinship (e.g. between refugees and nomads) and on Polisario governance (e.g. for access to the liberated territories).

The process transforming tribal authority to a nationstate is exemplified by the changes that occurred in camel brands. Branding refers to cauterizing unique symbols (marks) on an animals' body to communicate information about ownership, the owner's social status and grazing rights (Landais 2001; Humphrey 1974). Brands are also essential elements of identity in pastoral societies, as their collective character serves as an assertion of collective rights (e.g. of tribes) to specific resources (e.g. water, pastures) (Landais 2001; Bernus 1996). Among Sahrawi nomads, the process of branding camels was known as mhar (nar in Arabic) or elama; camels were usually branded on the neck or the thigh, or on the head or other visible part of the body (Caro Baroja 1955; Boyer 1962). Each tribe had its own brand, while larger tribes (e.g. the Reguibat in the 19th century) had different brands for major segmentary branches. Monteil (1952) recorded more than 25 brands used by Sahrawi tribes or their bands, about half of which incorporated letters or combinations of letters from the Arabic alphabet (e.g. the letters kaf and qaf for the Reguibat), the rest consisting of stylizations or abstract symbols.

The origins of brands were usually embedded in myths that tied into a single narrative the tribe's founder, the camel and the brand (Caro Baroja 1955, pp. 89-90). Camel brands conveyed the power of a tribe not only in terms of the number of camels held but also the location of camel herds in the territory - an indicator of territorial control. The brand, then, was a message conveyed to other pastoral groups about the related priority of access (or not) to the territory where those camels grazed. Thus, for pastoralists, the brand can be considered as a functional and symbolic equivalent of national flags for claiming territorial occupation and defining which human groups are granted access.

In the social revolution from a tribal to a state organization led by the Polisario, brands were also revolutionized. Today, all camels belonging to Polisario are marked on the neck with the letters 'FP' (Frente Polisario) followed by a number relating to a military region (from one to seven). For Polisario herds, this brand has 
completely displaced tribal marks, including a noticeable shift in the alphabet from Arabic to Latin, and a shift in the symbolic function of these herds' identity, from one based on tribal divisions to one based on Sahrawi unity. The Polisario adopted the branding conventions of the colonial authorities - Spanish and French colonial powers branded their herds with numbers rather than symbols. Polisario brands thus represent a rejection of traditional tribal symbols, reinforcing the ideological unity of the Sahrawi people beyond tribes and draw upon colonial symbols of state ownership. However, in continuity with the tribal past, in the liberated territories, the presence of camels marked with 'FP' indicates control over those territories and its resources and hence to whom people owe allegiance when using those resources.

With the recovery of camel husbandry and renewed access to a shared nomadic territory, refugees began to interact more intensively with nomads, often on the basis of kinship ties. Some nomads and their herds became integrated with the camel-based economy emerging in the refugee camps by functioning as reservoirs of camels (e.g. through loans) and camel-related knowledge and as a source of camel milk for refugees engaging in seasonal nomadism. Nomads in turn use the refugee camps as a commercial hub where they sell livestock, procure other items, access aid through refugee relatives and exchange food with refugees. As Wilson (2012) also noted, both refugees and nomads use the liberated territories to graze herds, interacting in a vast network of solidarity and reciprocity that is strengthened by kinship ties linking nomadic and refugee households. The common interest in camel husbandry has largely defined their relationships, served to strengthen social bonds that were severed with the dissolution of tribes and contributed to the development of a system of apparent mutual benefit.

The Sahrawi case is not the first in which refugee camps are shown to have a positive impact on regional economies by functioning as commercial hubs for local nomads who sell their surplus animals in the camps. Jansen (2011) reports the same for the Kakuma camps of Kenya. There, however, nomads and refugees are from different and rather antagonistic ethnic groups; the former are Turkana and the latter mainly Dinka, so that the relations between them are strictly based on trade. Among the Sahrawi, there is a deep interpenetration between refugees and nomads, so that patterns of exchange involve extended families and reciprocity, in addition to market exchange.

In the past, labour relations around camel husbandry were based on extended families and on structural differences within and between tribes. While poorer nomads relied on own and male kin labour, more powerful nomads and tribes (i.e. with hundreds of camels) exploited the labour of slaves and dispossessed nomads (e.g. members of a defeated tribe) (Caro Baroja 1955; Hart 1962). Today, nomads and refugees with small non-commercial herds still rely principally on family labour. However, in marketoriented enterprises, labour relations around camel husbandry have been largely commoditized, representing a break from the types of structural social differences that prevailed in the past. Commercially oriented herders use hired labour for camel management (e.g. feeding and watering) in and around the camps and contract shepherds to tend herds in the liberated territories. In the camps, labour is mainly provided by young refugees who have little formal education. In the liberated territories, refugee youth, Sahrawi nomads (local or from Mauritania) or, in some cases, sub-Saharan migrants are contracted. Shepherds are paid in cash rather than in kind whereas, in the past, they were paid in livestock, e.g. a camel in exchange for a year's labour.

\section{Cultural expectations and resistance around camel husbandry}

Refugees do not share the same attitudes towards the recovery of camel husbandry and renewed access to camel products, nor to the changes in camel husbandry and camel management. The refugee literature identifies two contrasting processes of cultural change in situations of exile (Couldrey and Morris 1999; Volpato and Waldstein 2014). The first is a tendency towards loss or abandonment of traditional culture, which is maintained only among elderly and specific, often marginal, groups. The second is a process of maintenance or recovery of traditional culture in order to promote the maintenance or recovery of productive activities and cultural identity. Among Sahrawi refugees, those who have been at least partly acculturated in the West and many other younger refugees who have never experienced nomadic life often express less concern about cultural continuity and regard camels and camel husbandry as 'backward' unless they are used as a means to make money. Older and more culturally conservative refugees stress the importance of livestock and livestock products, especially camel milk, and demand that their children meet their expectations by consuming camel milk and meat and travelling to the liberated territories.

Incentives to recover camel husbandry include the desire, especially of older refugees, to consume fresh camel milk and spend at least part of their lives in the badiya. Dedenis (2005) writes that sons continue to be motivated by the social obligation to provide fresh livestock products for their parents and to reconstitute herds; feelings of good health, pride, dignity and freedom are associated with a 'return to the badiya'. For the elderly, travelling through space to the badiya represents travel in time back to their youths. The badiya and its key elements (green deserts after rains, livestock, camel milk, tents) are emblematic of the culture they represent - of nomadic Sahrawi - and of associated values such as freedom and autonomy'. 
Forms of cultural resistance arose among refugees around technological change and intensification, where some are against the use of tanker trucks to water camels, which 'corrupts nomadic life'. Because traditional camel pastoralists have internalized camels' needs and the constraints of camel husbandry into their systems of knowledge and beliefs about the natural world, in their eyes, such change goes against the laws of nature. Some believe that, although tanker truck water comes from wells, it is not as good for camel's health as water that is directly extracted from wells and that camels watered directly with well water have greater strength and stamina ${ }^{j}$. Similarly, some traditional herders are 'against fodder' and are proud of the fact that they rely exclusively on free-grazing resources, believing that purchased fodder is bad for camels' health and lowers their resistance. The dialectic between 'innovation' and 'tradition' in camel management has, in some cases, assumed the form of an inter-generational struggle in which older men tend to favour traditional strategies. These forms of cultural resistance are probably an integral part of situations where profound change in the mode of subsistence and social relations are underway and have also been shown to occur among Sahrawi refugees in relation to concepts of illness, health and healing (Volpato and Waldstein 2014).

\section{The camel and Sahrawi identity}

All the people like us are We, and everyone else is They (Rudyard Kipling, We and They, 1926).

Kohler-Rollefson (1996, p. 283), in her work on the origin, use and dispersal of the one-humped camel in Asia, writes, 'The function of animals in human societies is usually not restricted to utilitarian purposes; they often fulfil important and culturally distinct symbolic and ritual roles...and quite frequently develop into hallmarks of identity.' Historically, among the Sahrawi, the camel was not only the material pillar of society but as well the cornerstone of Sahrawi tribal and nomadic identity. Several Sahrawi tribes' origin myths were based on camels (Caro Baroja 1955; Mercer 1976a); camels were central to Sahrawi beliefs, sayings and poems (Pinto Cebrián 1997); camel ownership defined prestige and social rank; and nomads identified with and felt affection for their camels and their local camel breeds. With recovery, much of the cultural significance of the camel as a symbol of ethnic identity has been revitalized, which is reinforced by the Polisario's efforts to create and sustain a national identity based on ethnicity, cultural heritage and territorial occupation.

Identity refers to feelings of belonging to a specific group based on a distinctive shared language, culture, social organization and ideology (Hurskainen 1990; Snow 2001).
Identities and their symbols are continuously constructed and re-constructed by redefining the differences between the self and the other, the cultural borders in which these differences are represented, and abandoning or adopting different key elements of identity (Drzewiecka 2002; Nagel 1994). As Corbet (2008) noted, contemporary Sahrawi are struggling in multiple ways to reconstruct their identity. The camel is a central, figurative and symbolic element that represents the Sahrawi and differentiates them from other (non-camel pastoralist) populations. The re-establishment of a relation with the badiya based on pastoral and nomadic practices reaffirms Sahrawi refugees' cultural identity based on their nomadic origins.

When the Polisario overturned tribal social structure, it eliminated the basis of social differences in favour of national unity, social equality and Sahrawi collective identity and citizenship and, at the same time, the cultural and political significance of camels was undermined. This revolution was necessarily cultural as well as social; tribalism in all its forms, as well as the material basis of this tribalism, were antithetical to the Polisario's project of building the basis for nationalist claims to the territory against other nationalist claims (e.g. Morocco). The Polisario thus not only eliminated (prohibiting reference to) tribal institutions and affiliations but as well discouraged the transmission of tribal myths of origin, which affirmed the distinct genealogical identities of the Sahrawi tribes as well as the symbolic significance of the camel as the material and cultural basis of these tribes' existence. As the Polisario nationalized camel herds, the camel was purged of any significance as the basis of tribal or personal power in favour of a cultural identity based on the unity of all ethnic Sahrawi under a 'modern' nation-state. However, the camel was too potent a symbol both of Sahrawi ethnic identity and of Sahrawi claims to their traditional nomadic territory to discard wholly or permanently. The camel was later to be recovered as a symbol of Sahrawi unity vis-àvis other populations and so regained a prominent place in Sahrawi cultural identity not only among refugees and nomads engaged in camel husbandry but as well in official Polisario discourse and practices. For the Polisario, the rebirth of the camel's symbolic significance was functional to claims of independence. Camel husbandry reinforces the Polisario's claims to nation-statehood by legitimizing control over the former territory pertaining to the Sahrawi nomadic tribes both through occupation (people and animals) and use and by providing for the national welfare and reducing dependence on foreign aid by means of state food production and redistribution. The camel and camel husbandry also serve to legitimize claims to national identity by representing the basis of a shared ethnic, cultural and political identity, as well as symbolizing the differences between the Sahrawi and other populations, particularly the Moroccans. 
The contrasting political ideologies and claims of the Polisario, on the one hand, and of the Morocco Government, on the other hand, constitute a crucial axis of the dispute over control of Western Saharan territory. Under the Polisario, Sahrawi identity has been reinforced on the basis of differences between the Sahrawi and the Moroccans, whose cultural practices are explicitly and implicitly contrasted (Chamberlain 2005). The SADR's Ministry of Information produces educational and informational material for refugees that stress this contrast in terms of language, food, dress and women's roles (Allan 2010) and, as a result, 'many aspects of everyday Saharawi existence become cultural markers' (Chamberlain 2005, p. 27). This is also the case with ethnobotanical knowledge associated with the desert environment and camel husbandry (Volpato and Puri 2014), which contrasts with Morocco's agricultural traditions. The dispute over Western Sahara territory thus aims to 'hegemonise a collective social imaginary about what it is to be Saharawi, who the Sahrawis are and who the 'others' are that delineate the frontier of 'our Sahara' (San Martin 2005, p. 587). Camels and camel husbandry are part of this dispute and are central to the public representation of Sahrawi political identity. Camels appear in refugees' and Polisario's discourses as the basis of a 'stolen' nomadic life in the badiya, where 'pastures are good' and 'camels gain health', in contraposition to neighbouring areas (e.g. Morocco to the north, central Mauritania to the south) where 'camel diseases are widespread' and 'the climate is too wet for camels'. Below, we present three examples of this re-appropriation of the camel as a symbol of cultural and national identity in relation to the figure of the deyar (a nomad who searches for stray camels), to the skills needed to slaughter camels and to the use of camel milk in political contexts.

In Sahrawi nomadic culture, the deyar is a very knowledgeable and experienced nomad camel tracker who locates camels that have strayed in the desert and returns them to their herds. Deyars read tracks in the sand and infer a great amount of information from their shape, depth, distribution, direction, etc. Deyars are highly respected for their knowledge, skills and intimate relation with the desert environment. With the collapse of nomadism during the war and the changes that ensued in camel management (e.g. increased reliance on motor vehicles and binoculars), the number of deyars drastically declined and their skills are being lost. But if their physical presence is dwindling, their cultural significance is not: on the contrary, deyars have a prominent place in present-day Sahrawi literature and poetry (see for example Ebnu 2008; Boicha et al. 2003; Bahia 2007; Moure 2004), where they often represent the badiya itself and the lost relationship with and knowledge of Western Sahara territory. At the same time, the deyar's search for stray camels has come to symbolically represent the Sahrawi's search for the camels lost with the war and, in a wider sense, of the search for their lost nomadic life, independence, and freedom in the territory of Western Sahara, and hence an assertion of the claim to the territory.

Among the cultural practices that the Sahrawi contrast explicitly with the Moroccans are camel slaughter skills, which reflect the intimate relation between camels and the Sahrawi as well as the alleged Moroccan's ignorance of camels. The contrast is stressed by a young Sahrawi author who describes a camel slaughterhouse on the outskirts of El Aaiún city in Moroccan-controlled Western Sahara, where camels can be heard crying out in suffering, which he contrasts with Sahrawi practices known as nosh (Autores Varios 2009, pp. 89-90) ${ }^{\mathrm{k}}$. One of the nosh prescriptions dictates that, when slaughtering a camel, suffering must be minimal, which is possible only through the skills and experience of the slaughterer, which are transmitted between herders across generations as part of Sahrawi cultural heritage. So, for example, when a young Sahrawi attended an encounter with King Hassan II in 1979 organized by the Moroccan authorities, they sacrificed a camel: it 'was horrible, that animal was crying a lot...those people don't have any idea of how a camel must be killed' (A.A. 1979). Indeed, if the main arteries between the neck and the thorax are severed with a single cut, death occurs instantaneously, whereas if the cut is not expertly executed, death is delayed and the animal suffers (Farah and Fischer 2004). In pre-colonial Sahrawi society, usually, the eldest or most respected man slaughtered camels, which was forbidden to lower social groups (e.g. slaves). Thus, a contraposition that was internal to the social system (slaves-camel owners) has been conceptually reorganized as an external contraposition (Moroccans-Sahrawi), which is functional to Polisario political struggles and claims to Sahrawi unity.

Since at least 1999, the struggle for Sahrawi nationhood has extended into that part of Western Sahara under Moroccan control where the Sahrawi experience social and economic discrimination and participate in nationalistic demonstrations and riots (San Martin 2005). In this context, camels are an issue; a group of former nomads from El Aaiún is currently campaigning for compensation for the camel herds that Moroccan troops killed during the war, which requires the Moroccan authorities' recognition that troops were ordered to butcher Sahrawi herds, a fact that Moroccan authorities deny (Shelley 2004). Such acts are contrasted with the Sahrawi's affection for the animal and the social and the cultural importance attached to camels and camel products. Sahrawi who struggle for independence in the Moroccan-controlled Western Sahara adopt camel milk as a symbol of their ethnic and national identity while reflecting the difference with Moroccans' sedentary lifestyles and identities. Reports show that, in April 2006, when Moroccan authorities released Sahrawi activists from prison and again in Agadir, in 2007, when 
Sahrawi students were released for having publically demanded independence for Western Sahara, their Sahrawi supporters greeted them with cups of camel milk and dates (SPS 2006, 2007), just as Sahrawi nomads returning from long desert treks were received in their camps in precolonial times.

Morocco is also promoting camel husbandry in the part of Western Sahara under its control while attempting to appropriate the camel as a symbol at a sub-national (i.e. ethnic, tribal) level, thus proposing that Sahrawi nomadic heritage is part of Moroccan national heritage (MartinMárquez 2006; Julien 2004). Polisario calls for Sahrawi unity against tribal identity, while Morocco tries to promote and enhance tribal identity and downplay or deny the existence of Sahrawi national unity (Corbet 2008). Moroccan authorities are attempting to undermine the Polisario's monopoly over the politicization of Sahrawi nomadic culture, exalting the camel and its characteristics. This has occurred in the context of a parallel recovery of camel husbandry in Moroccan-controlled Western Sahara which has been on-going since the 1990s, especially with the emergence of commercial enterprises producing and selling camel milk and meat (Pazzanita 2006a, b; Michel et al. 1997). The Moroccan Government and local authorities increasingly fund camel husbandry, supporting it through direct aid (e.g. subsidies for camel purchases), cooperation programmes that distribute free veterinary medicines and vaccines and implement applied research (e.g. epidemiological studies) (El Abrak 2000; Essemlali 2008; Michel et al. 1997). Today, the Moroccan Government and media portray camel husbandry as an integral part of the Moroccan economy and promote the camel milk and meat consumption (El-Katab 2008). Among other events promoting camel meat and milk in Western Sahara, the Moroccan authorities organized an International 'Salons of the Dromedary' in 2008 and 2009 in what they call the 'Southern Provinces' or 'Moroccan Sahara' to celebrate 'the central symbol of the culture and life of Saharan inhabitants', as the francophone Moroccan newspaper Le Matin du Sahara et du Maghreb (Essemlali 2008) reported: a clear example of the attempt to reposition Sahrawi nomadic heritage as part of Moroccan heritage. Thus, a struggle to ideologically appropriate Sahrawi nomadic cultural heritage continues between Moroccan authorities and the Polisario, with the former aiming to incorporate it as a specific ethnic/tribal heritage within Moroccan national culture and the latter aiming to recover nomadic cultural heritage as the foundation of Sahrawi independence and against Moroccan claims.

\section{Conclusions}

This study has addressed the material and cultural importance of camels and camel husbandry among Sahrawi refugees, as well as their efforts to recover their territory and productive activities and promote their shared nomadic heritage and cultural identity. The case illustrates both how refugees struggle to recover their livelihoods in contexts of forced displacement and sedentarization in refugee camps and how this struggle is informed by pre-exile modes of subsistence and cultural values. The camel was central to Sahrawi nomadic society both materially and culturally. With war and forced displacement, the Sahrawi lost most of their camels - it took decades for refugees to recover camel husbandry by regaining access to camels, grazing territory and camel-associated knowledge and to establish reciprocal relations around camel husbandry in the liberated territories with remaining nomads. Although this recovery is sustained by traditional values and practices related, for example, to camel milk consumption and redistribution, fundamental changes have also occurred: the camel lost its traditional functions as a means of transport, warfare and non-monetary exchange; management has intensified with the use of fossil fuels and motor vehicles and increasing reliance on purchased fodder and other inputs rather than on desert grazing resources; and camel products as well as access to camels and labour have been largely commoditized. The camel has also been appropriated as a symbol of Sahrawi cultural identity both by refugees and in Polisario discourse and practice, which asserts the Sahrawi's nomadic cultural heritage as a key element of a national identity legitimating claims to nationhood and traditional territories for the Sahrawi people.

The findings of this study are significant for understanding both refugees' individual and collective agency towards cultural and economic recovery and dispossessed pastoralists' struggle to rebuild herds and livestock-based forms of livelihood. We have expanded our knowledge of Sahrawi refugees' agency and their re-engagement with pastoralism and the liberated territories and also provided a framework for more generally conceptualizing some of the processes by which refugees living in camps engage in productive activities, how these are informed by their culture, access to means of production and financial capital and how they are embedded within larger-scale socio-economic change processes including commodification and migration. The findings also contribute to the understanding of human-nature relations in contexts of forced displacement and of the means by which refugees re-engage with traditional productive activities, knowledge and environmental relations, in the process adapting (and reinventing) the past to new conditions and values arising from their experience as refugees. Knowledge of these processes is important not only to understand refugees' and displaced people's struggles but also to comprehend broader cultural and social processes taking place in refugee camps (and, within this, the role of food aid) and to formulate ways in which the international community can address refugees' problems within these processes. 
NGOs working in refugee camps can use studies about the recovery of refugees' livelihoods to identify and implement means to assist this recovery.

Although the recovery of camel husbandry is rather limited in terms of the numbers of refugees and camels involved, it is likely to continue into the future as refugees continue to break the chains of food dependency, as long as it can be sustained by rains, and as long as access to camels and to the liberated territories remain assured. The strategy that refugees pursue leads towards greater integration of refugee camps with wider economic and social networks, but this depends on the continued existence of the camps and of international aid. As long as this trend continues, there will be an increasing number of camels and greater integration between refugees and nomads (often within extended families), creating a single productive network between the refugee camps and the liberated territories. If the referendum for Sahrawi self-determination is eventually held $^{\mathrm{m}}$ and refugees move back to Western Sahara, some refugees might return to nomadism, merging with nomads on both side of the berm and using Western Sahara towns as commercial hubs. In this scenario, the Polisario Front might redistribute its camels to refugees, in a sort of concluding cycle in which the herds that the Polisario acquired from disbanding nomads at the beginning of the war and used to support refugees in the decades of exile, once again become the basis for a return to desert nomadic pastoralism.

\section{Endnotes}

${ }^{a}$ Loans where those who borrow camels assume the costs of managing them and can use them for transport, milk production and wool.

b The data and information discussed in this paper are drawn from fieldwork carried out by the first author between 2006 and 2010 in the Sahrawi refugee camps and in the liberated territories of Western Sahara. Fieldwork included a survey (about camels owned, use of camels and camel products, extent to which the herd is used for market-oriented activities, camel management, distribution of camel products, personal history of camel husbandry; $n=74$ ) and semi-structured interviews $(n=36)$ with refugee and nomadic camel owners, and a survey $(n=62)$ with refugees' households about camel meat and milk procurement and consumption. Data were analysed using SPSS and Excel to derive descriptive statistics. The ethical guidelines followed were those adopted by the American Anthropological Association (1998) and the International Society of Ethnobiology (2006).

'See Volpato and Rossi (2014) for a photographic description of the liberated territories and of local nomads' life.

${ }^{d}$ In 2005, the Polisario held about 40,000 sheep, 30,000 goats and 25,000 camels (DNV-RASD 2005).

${ }^{\mathrm{e}}$ This census might have missed between 7 and 10,000 nomads (Gaudio 1993, p. 61). f The Moroccan Army also poisoned wells to ensure that those people and herds that were not eliminated by the bombings would be unable to occupy the territory (Lippert 1987).

gThere are no data available about the number of camels that Polisario obtained this way.

${ }^{\mathrm{h}}$ The SADR is a partially recognized state that claims sovereignty over the territory of Western Sahara. It was established by the Polisario Front in 1976 to provide a new entity to fill the political void left by the departing Spanish colonizers. The SADR government controls about $20 \%$ of the Western Sahara territory.

'An association between 'freedom' and the 'badiya' is often found in nomadic Sahrawi poetry, which was largely based on the description and celebration of badiya resources and landscapes. For example, the most renowned living Sahrawi poet, Mohamed Mustafa Salem (known as Badi) said, 'In the badiya a man is free to do everything he pleases, with his life, with his livestock, with his water. He is owner of himself. Who does not live in the badiya cannot be owner of himself, in any other place...Every minute of life one feels free, very free. Nothing is better in the badiya than when a friend comes, a person you esteem and to whom you can offer everything you can imagine' (cited in Gimeno Martín and Pozuelo 2010, pp. 11-12) [own translation from Spanish].

${ }^{j}$ According to Elmi (1989), Ceeldheer pastoralists of Somalia do not like to water their camels from wells with a motorized pump for two reasons: the camels do not like the water because it smells of diesel, and water stored in metal tanks is cooler than that from the bottom of the well, and thus, camels do not like it and will not drink it to capacity.

${ }^{\mathrm{k}}$ Nosh literally refers to tethering camels by grabbing them by the tail.

${ }^{\mathrm{l}}$ See Wallerstein (1987) for a discussion of the political manipulation of concepts of identity as 'national,' 'ethnic' or 'racial' where 'peoplehood' is 'in no sense a primordial stable social reality, but a complex clay-like historical product of the capitalist world economy through which the antagonistic forces struggle with each other' (p. 85), which seems entirely appropriate in the context of Western Sahara.

${ }^{\mathrm{m}}$ The ceasefire agreement of 1991 included a referendum for self-determination originally scheduled for 1992, in which the Sahrawi would have the option to decide between independence and integration with Morocco. However, this referendum was never held and is still in the UN's to-do list (Pazzanita 2006a, b).

\section{Competing interests}

The authors declare that they have no competing interests.

\section{Authors' contributions}

GV designed the methods approach, carried out field work, analysed the data, composed the literature review and drafted the manuscript. PH participated in the study design, in the literature review and in drafting the manuscript, as well as editing it. Both authors read and approved the final manuscript. 


\section{Authors' information}

GV is a PhD candidate in social sciences and anthropology at the University of Wageningen, The Netherlands. His current research interests include ethnobiology and forced displacement, ethnomedicine and ethnoveterinary medicine, particularly concerning camels. PH is a Professor in Social Sciences at the University of Wageningen, the Netherlands, and Honorary Professor in Biocultural Diversity and Ethnobiology at the School of Anthropology and Conservation at the University of Kent in the UK. Her current research interests include human adaptation to biodiversity change, biodiversity-related tipping points in socio-ecological systems and gender and biodiversity management and conservation.

\section{Acknowledgements}

We are very grateful to many Sahrawi for the patience, kindness and hospitality that they showed during fieldwork. We thank the Italian NGO Africa 70 especially Alessandro Broglia, Sara Di Lello and Davide Rossi - and the Veterinary Service of the SADR (Sahrawi Arab Democratic Republic) and its director Saleh Mohamed Lamin for logistical support and cooperation. Our gratitude also extends to the Polisario personnel who accompanied Gabriele Volpato in his travels across the liberated territories of Western Sahara. Funds were granted to Gabriele Volpato by Ceres Research School of Wageningen University, The Netherlands, as part of his PhD research on the subsistence practices and ethnobiological knowledge of Sahrawi refugees.

\section{Received: 2 April 2014 Accepted: 14 May 2014}

\section{Published online: 27 June 2014}

\section{References}

A.A. 1979. La extraña aventura de Chefid Mohamed. Madrid: El Pais.

Abbas, B, AA Al-Qarawi, and A Al-Hawas. 2002. The ethnoveterinary knowledge and practice of traditional healers in Qassim Region, Saudi Arabia. Journal of Arid Environments 50: 367-379.

Abeiderrahmane, N. 2005. Modern Dairy Products from Traditional Camel Herding: An Experience in Mauritania. In Desertification Combat and Food Safety, Series I: Life and Behavioural Sciences, vol. 362, ed. B Faye and P Esenov. Amsterdam: IOS.

Adano, WR, and K Witsenburg. 2005. Once Nomads Settle: Assessing Process, Motives and Welfare Changes on Marsabit Mountain. In As Pastoralists Settle: Social, Health, and Economic Consequence in Marsabit District Kenya, ed. E Fratkin and EA Roth, 105-136. New York and London: Kluwer Academic/Plenum.

Allan, J. 2010. Imagining Saharawi women: the question of gender in POLISARIO discourse. The Journal of North African Studies 15(2): 189-202.

American Anthropological Association. 1998. Code of Ethics of the American Anthropological Association. Accessed 15 March 2006. www.aaanet.org/ profdev/ethics/upload/ethicscode1998.pdf.

Antoine-Moussiaux, N, B Faye, and GF Vias. 2007. Tuareg ethnoveterinary treatments of camel diseases in Agadez area (Niger). Tropical Animal Health and Production 39: 83-89.

Arkell, T. 1991. The decline of pastoral nomadism in the Western Sahara. Geography 76(331): 162-166.

Bahia, MA. 2007. Versos Refugiados. Poesía Saharaui Contemporanea. Alcala de Henares: Universidad de Alcala.

Bandura, A. 2006. Toward a psychology of human agency. Perspectives on Psychological Science 1(2): 164-180.

Bernus, E. 1996. Marques de propriété touarègues et pierres tombales (plaines au sud-ouest de l'Aïr). Sahara 8: 7-18.

Bhatia, M. 2001. The Western Sahara under Polisario control. Review of African Political Economy 28: 291-298.

Blench, R. 2001. 'You can't go Home again': Pastoralism in the new Millennium. London: Overseas Development Institute.

Boicha, L, L Lehsan, S Ebnu, S Abdalahi, AS Iselmu, and C Mahmud. 2003. Bubisher. Poesía Saharaui Contemporánea. Las Palmas de Gran Canaria: Puentepalo.

Bollig, M, M Schnegg, and H Wotzka. 2013. Pastoralism in Africa: Past, Present and Future. Oxford: Berghahn.

Boneh, D. 1984. Returning to pastoralism: three cases from the Negev Bedouin. Nomadic Peoples 15: 41-50.

Boulay, S. 2004. Quand un Objet Change de Statut: Trajectoire de la Tente Dans la Société Maure (Mauritanie). Ethnographiques.org 6. http://www. ethnographiques.org/2004/Boulay.html.

Boyer, JR. 1962. Contribution à l'étude de l'élevage Camelin au Sahara Occidental. Le Regueibat et son Chameau. Paris: Ecole Nationale Veterinaire D'Alfort.
Brazier, C. 1997. Light in the Darkness. New Internationalist magazine (297). http://www.newint.org/features/1997/12/05/light/.

Briggs, LC. 1960. Tribes of the Sahara. Cambridge: Harvard University Press.

Broglia, A, and G Volpato. 2008. Pastoralism and displacement: Strategies and limitations in livestock raising by Sahrawi refugees after thirty years of exile. Journal of Agriculture and Environment for International Development 102(1/2): 105-122.

Bulliet, R. 1975. The Camel and the Wheel. Cambridge: Harvard University Press.

Camacho, A. 1987. Pastores en la guerra. Madrid: El Pais.

Capot-Rey, R. 1962. The Present State of Nomadism in the Sahara. The Problems of the Arid Zone. Paris: UNESCO.

Caratini, S. 1989. Les Rgaybat (1610-1934). 2: Territoire et Société. Paris: L'Harmattan.

Caratini, S. 2000. Système de parenté Sahraoui. L'impact de la révolution L'Homme 154-155: 431-456.

Caratini, S. 2003. La Republique des Sables: Anthropologie d'une Revolution. Paris: Editions Harmattan.

Caratini, S. 2007a. La prison du temps. Les mutations sociales à l'oeuvre dans les camps de réfugiés sahraouis Deuxième partie: l'impasse Afrique contemporaine 2(222): 181-197.

Caratini, S. 2007b. La prison du temps. Les mutations sociales à l'oeuvre dans les camps de réfugiés sahraouis. Première partie: la voie de la révolution. Afrique contemporaine 1(221): 153-172.

Caro Baroja, J. 1955. Estudios Saharianos. Madrid: Consejo Superior de Investigaciones Cientificas.

Catley, A. 2006. Use of participatory epidemiology to compare the clinical veterinary knowledge of pastoralists and veterinarians in East Africa. Tropical Animal Health and Production 38: 171-184.

Cavaglieri, S. 2005. Livelihood Strategies and Food Security in Refugee Camps. Rome: University of Roma Tre.

Censo-74. 1974. Censo, ed. Censo y Estadistica Servicio de Registro de Poblacion. El-Ayoun: Servicio de registro de poblacion, censo y estadistica.

Chaibou, M, and B Faye. 2005. Fonctionnement des élevages camelins de la zone périurbaine d'Agadez au Niger: enquête typologique. Revue d'Élevage et de Médecine Vétérinaire des Pays Tropicaux 58(4): 273-283.

Chamberlain, R. 2005. Stories of a Nation: Historical Narratives and Visions of the Future in Sahrawi Refugee Camps. Oxford: Refugee Studies Centre, University of Oxford.

Chatty, D. 1980. The Pastoral Family and the Truck. In When Nomads Settle: Processes of Sedentarization as Adaptation and Response, ed. P Salzman, 80-94. New York: Praeger.

Chatty, D. 1986. From Camel to Truck: The Bedouin in the Modern World. New York: Vantage.

Chatty, D. 2005. Nomadic societies in the Middle East and North Africa: Entering the 21st century. In Handbook of oriental studies. Section 1 The Near and Middle East. Leiden: Brill.

Corbet, A. 2008. Nés Dans les Camps. Changements Identitaires de la Nouvelle Génération de Réfugiés Sahraouis et Transformation des Camps. Paris: École des Hautes Études en Sciences Sociales.

Couldrey, M, and T Morris. 1999. Culture in Exile. Forced Migration Review. Oxford: The Refugee Studies Centre in association with the Norwegian Refugee Council/Global IDP Project.

Crivello, G, E Fiddian, and D Chatty. 2005. The transnationalisation of care: Sahrawi refugee children in a Spanish host program. Oxford: Refugee Studies Centre.

Crivello, G, E Fiddian, and D Chatty. 2006. Holidays in peace: Sahrawi children visit Spain. FMR 25: 59-60.

Dahl, G. 1979. Suffering Grass: Subsistence and Society of Waso Borana. Stockholm Studies in Social Anthropology. Stockholm: University of Stockholm.

de Juan Canales, D. 2009. Imaginación y reacción en los Campamentos de refugiados saharauis: construcción de la cotidianeidad e identidad frente al otro extranjer (nasrani) en el contexto de la diáspora. Perifèria - Revista de recerca i formació en antropologia 10: 1-24.

de Juan Canales, D. 2010. Emergencia civil y economía del refugio en los campamentos de refugiados saharauis de Argelia. Gazeta de Antropologia 26(1): 11.

Dedenis, J. 2005. La Mobilité Régionale de la Société Sahraouie des Camps de Réfugiés. Une Ressource Pour un Mieux-Vivre? Poitiers: Université de Poitiers.

DNV-RASD. 2005. Census 2005. República Árabe Democrática Sahrawi, Rabuni, Polisario refugee camps: Dirección Nacional de Veterinaria, Ministerio de Salud Pública Sahrawi, RASD.

DNV-RASD. 2007. Census 2007. República Árabe Democrática Sahrawi, Rabuni, Polisario refugee camps: Dirección Nacional de Veterinaria, Ministerio de Salud Pública Sahrawi, RASD. 
Drzewiecka, JA. 2002. Reinventing and contesting identities in constitutive discourses: between Diaspora and its others. Communication Quarterly 50(1): 1-23.

Ebnu, A. 2008. Nómadas en el Exilio. Marbella: Asociación Cultural Almenara.

El Abrak, A. 2000. Encadrement Sanitaire du Cheptel Camelin au Maroc. In Maladies Parasitaires et Infectieuses du Dromadaire, ed. A Dakkak, 9-14. Rabat: Actes Editions.

Elizondo, L, CM Mehdi, and M Sanz. 2008. Microcréditos en el Sáhara. Manual Para la Solicitud de Crédito en los Campamentos Saharauis. Bilbao: Hegoa.

El-Katab, A. 2008. La viande du dromadaire, un produt sahraoui jusque-lá inexploité. Rabat: Libération.

Ellen, R, SJ Lycett, and SE Johns. 2013. Understanding Cultural Transmission in Anthropology: A Critical Synthesis. Oxford: Berghahn Books.

Elmi, AA. 1989. Camel Husbandry and Management by Ceeldheer Pastoralists in Central Somalia. Mogadishu: Botany and Range Science Department, Faculty of Agriculture, Somali National University.

Essemlali, M. 2008. Provinces du Sud: Le dromadaire symbole central dans la culture sahraouie. Rabat: Le Matin.

Farah, R. 2008. Refugee camps in the Palestinian and Sahrawi national liberation movements: A comparative perspective. Journal of Palestinian Studies 38(2): 76-93.

Farah, Z, and A Fischer. 2004. Milk and Meat from the Camel: Handbook of Products and Processing. Zurich: vdf Hochschulverlag AG.

Farah, Z, M Mollet, M Younan, and R Dahir. 2007. Camel dairy in Somalia: limiting factors and development potential. Livestock Science 110: 187-191.

Faye, B. 2009. Pauvreté et Solidarité Chez les Peuples Pastoraux. In L'élevage, Richesse des Pauvres, ed. GB Duteurtre and B Faye, 77-87. Versailles: QUAE.

Faye, B, M Bengoumi, and A Barkat. 2003. Le Développement des Systémes Camélins Laitiers Périurbains en Afrique. In Lait de Chamelle Pour I'Afrique, 115-125. Niamey: Atelier sur la Filière Laitiére Caméline en Afrique Niamey, 5-8 November, 2003. Niamey: FAO Production et Santé Animales.

Faye, B, H Madani, and AH El-Rouili. 2014. Camel milk value chain in Northern Saudi Arabia. Emir J Food Agric 26(4): 359-365.

Fiddian-Qasmiyeh, E. 2011. The pragmatics of performance: Putting 'faith' in aid in the Sahrawi refugee camps. Journal of Refugee Studies 24(3): 533-547.

Gaudio, A. 1993. Les Populations du Sahara Occidental. Editions Karthala. Paris.

Gauthier-Pilters, H. 1961. Observations sur l'ecologie du dromedaire dans le Sahara Nord-Occidental. Mammalia 25(2): 195-280.

Gertel, J, and R Le Heron. 2011. Economic Spaces of Pastoral Production and Commodity Systems: Markets and Livelihoods. Farnham: Ashgate.

Gimeno Martín, JC, and LM Pozuelo. 2010. Memorias orales en el Sáhara Occidental: la poesía en hasanía. 7th Congress of African Studies. Lisboa 21: 1-27.

Golooba-Mutebi, F, and SM Tollman. 2004. Survival to livelihood strategies for Mozambican refugees in South Africa. FMR 20: 28-29.

Grewal, NK. 2011. lodine Status and Thyroid Function Among Lactating Women in Saharawi Refugee Camps, Algeria. Akershus: Akershus University College.

Hart, DM. 1962. The social structure of the Rgibāt Bedouins of the Western Sahara. Middle East Journal 16(4): 515-527.

Hart, DM. 1998. The Rgaybat: Camel nomads of the Western Sahara. The Journal of North African Studies 3(4): 28-54.

Harvey, P, and J Lind. 2005. Dependency and Humanitarian Relief: A Critical Analysis. London: Humanitarian Policy Group, Overseas Development Institute.

Henjum, S, I Barikmo, AK Gjerlaug, AM Lehabib, A Oshaug, TA Strand, and LE Torheim. 2010. Endemic goitre and excessive iodine in urine and drinking water among Saharawi refugee children. Public Health Nutrition 13(9): 1472-1477.

Hernández, R. 2013. La Semilla de la Verdad. Sáhara Documental. http://www. elmundo.es/elmundo/2013/10/20/internacional/1382244113.html. Accessed 20 Oct 2013.

Herren, UJ. 1992. Cash from camel milk: the impact of commercial camel milk sales on garre and gaaljacel camel pastoralism in southern Somalia. Nomadic Peoples 30: 97-113.

Herz, M. 2013. From Camp to City: Refugee Camps of the Western Sahara. Zürich: ETH Studio Basel, Lars Müller.

Homewood, K. 2008. Ecology of African pastoralist societies. Oxford: James Currey Ltd.

Horowitz, MM, and P Little. 1987. African Pastoralism and Poverty: Some Implications for Drought and Famine. In Drought and Hunger in Africa: Denying Famine a Future, ed. M Glantz. Cambridge: Cambridge University Press.

Horst, C. 2006a. Refugee livelihoods: Continuity and transformations. Refugee Survey Quarterly 25(2): 6-22.

Horst, C. 2006b. Transnational Nomads. How Somalis Cope With Refugee Life in the Dadaab Camps of Kenya. Studies in Forced Migration. New York: Berghahn Books.
Hultman, T. 1977. The struggle for Western Sahara. Issue: A Journal of Opinion 7(1): $27-32$.

Humphrey, C. 1974. Horse brands of the Mongolians: a system of signs in a nomadic culture. American Anthropologist 1: 471-488.

Hurskainen, A. 1990. Levels of identity and national integrity: the viewpoints of the pastoral Maasai and Parakuyo. Nomadic Peoples 25-27: 79-92.

International Society of Ethnobiology. 2006. ISE Code of Ethics (with 2008 additions). www.ethnobiology.net/code-of-ethics/.

Jacobsen, K. 2002. Livelihoods in conflict: the pursuit of livelihoods by refugees and the impact on the human security of host communities. International Migration 40(5): 95-123.

Jacobsen, K. 2005. The Economic Life of Refugees. Bloomfield: Kumarian.

Jansen, BJ. 2011. The Accidental City: Violence, Economy and Humanitarianism in Kakuma Refugee Camp, Kenya. Wageningen: Wageningen University.

Julien, Z. 2004. L'identité Sahraouie en Questions. In L'Ouest Saharien, ed. A Abjean and Z Julien, 131-231. Paris: L'Harmattan.

Keenan, J. 2003. The last nomads. Nomadism amongst the Tuareg of Ahaggar (Algerian Sahara). Journal of North African Studies 8(3-4): 163-192.

Khalif, ZK, and G Oba. 2013. Gaafa dhaabaa - the period of stop': Narrating impacts of shifta insurgency on pastoral economy in northern Kenya, c. 1963 to 2007. Pastoralism: Research, Policy and Practice 3: 1-14.

Kohler-Rollefson, I. 1996. The one-Humped Camel in Asia: Origin, Utilization and Mechanisms of Dispersal. In The Origins and Spread of Agriculture and Pastoralism in Eurasia, ed. DR Harris, 282-292. London: UCL.

Köhler-Rollefson, I. 2003. A treatise on life with camels. German Research 1: 15-19

Koser, K, and N Al-Ali. 2001. New Approaches to Migration? Transnational Communities and the Transformation of Home. London: Routledge.

Landais, E. 2001. The marking of livestock in traditional pastoral societies. Revue scientifique et technique de l'Office international des épizooties 20(2): 445-462.

Lentz, E, CB Barrett, and J Hoddinott. 2005. Food aid and dependency: implications for emergency food security assessments. IFPRI Discussion Paper 12(2).

Lippert, A. 1987. The human costs of War in Western Sahara. Africa Today 34(3): 47-59.

Lippert, A. 1992. Sahrawi women in the liberation struggle of the Sahrawi people. Signs 17(3): 636-651.

López Belloso, M, and I Mendia Azkue. 2009. Local human development in contexts of permanent crisis: Women's experiences in the Western Sahara. Journal of Disaster Risk Studies 2(3): 159-176.

Mace, $\mathrm{RH}$, and Al Houston. 1989. Pastoralist strategies for survival in unpredictable environments: a model of herd composition which maximises household viability. Agricultural Systems 30

Martin, P. 1976. Tribesmen swell Polisario ranks. London: The Times.

Martin-Márquez, S. 2006. Brothers and others: fraternal rhetoric and the negotiation of Spanish and Saharawi identity. Journal of Spanish Cultural Studies 7(3): 241-258.

McCabe, J. 1987. Drought and recovery: livestock dynamics among the Ngisonyoka Turkana of Kenya. Human Ecology 15(4): 371-390.

McCabe, J. 1990. Success and failure: the breakdown of traditional drought coping institutions among the pastoral Turkana of Kenya. Journal of Asian and African Studies 25(3-4): 146-160.

Mercer, J. 1976a. The cycle of invasion and unification in the Western Sahara. African Affairs 75(301): 498-510.

Mercer, J. 1976b. Spanish Sahara. London: G. Allen.

Meyer, S. 2006. The 'refugee aid and development' approach in Uganda: Empowerment and self-reliance of refugees in practice. New Issues in Refugee Research. Research Paper 131. Geneva.

Mezhoud, S, and C Oxby. 2013. Disentangling 'Forced displacement' from Pastoral Mobility: Recovery and Reconstruction in the Sahel and in South Sudan. In Modern Pastoralism and Conservation: Old Problems, new Challenges, ed. T Sternberg and D Chatty, 210. Cambridge: The White Horse.

Michel, JF, M Bengoumi, P Bonnet, K Hidane, K Zro, and B Faye. 1997. Typologie des systèmes de production camelins dans la province de Laâyoune, Maroc. Revue d'Élevage et de Médecine Vétérinaire des Pays Tropicaux 50(4): 313-323.

Mohamed, HA, and AN Hussein. 1996. Pastoralists: their knowledge untapped. Journal of Camel Practice and Research 3: 143-145.

Monteil, V. 1952. Essai sur le Chameau au Sahrara Occidental. Etudes Mauritaniennes. Saint-Louis du Senegal: Centre IFAN - Mauritanie.

Morando, M. 2006. La Diaspora Saharawi in Italia. Bologna: Universitá degli Studi di Bologna.

Moure, G. 2004. La Zancada del Deyar. Barcelona: El Cobre.

Mundubat. 2007. Acta de la II Mesa de Coordinación y Concertación. In Mesa de Concertación de Soberanía Alimentaria del Sahara. Madrid. 
Mundy, JA. 2007. Performing the nation, pre-figuring the state: the Western Saharan refugees, thirty years later. Journal of Modern African Studies 45(2): 275-297.

Nagel, J. 1994. Constructing ethnicity: creating and recreating ethnic identity and culture. Social Problems 41(1): 152-176.

Noor, IM, AY Guliye, M Tariq, and BO Bebe. 2013. Assessment of camel and camel milk marketing practices in an emerging peri-urban production system in Isiolo County, Kenya. Pastoralism: Research, Policy and Practice 3(28).

Nori, M, MB Kenyanjui, MA Yusuf, and FH Mohammed. 2006. Milking drylands: the marketing of camel milk in North-east Somalia. Nomadic Peoples 10(1): 9-28.

Pazzanita, AG. 2006a. Western Sahara: anatomy of a stalemate. International Journal of African Historical Studies 39(1): 151-154.

Pazzanita, AG. 2006b. Historical Dictionary of Western Sahara. Historical Dictionaries of Africa, 3rd ed. Oxford: The Scarecrow.

Pinto Cebrián, F. 1997. Proverbios Saharauis. Madrid: Miraguano Ediciones.

Ryle, J. 1992. Notes on the repatration of Somali refugees in Ethiopia. Disasters 16(2): 160-168

Salzman, PC. 1980. When Nomads Settle: Processes of Sedentarization as Adaptation and Response. New York: Praeger.

San Martin, P. 2005. Nationalism, identity and citizenship in the Western Sahara. The Journal of North African Studies 10(3): 565-592.

San Martin, P. 2010. Western Sahara: The Refugee Nation. Cardiff: University of Wales Press.

Shelley, T. 2004. Endgame in Western Sahara: What Future for Africa's Last Colony? London: Zed Books.

Shelley, T. 2010. Sons of the Clouds. http://www.redpepper.org.uk/sons-of-theclouds/. Accessed 2 Sept 2011

Snow, DA. 2001. Collective Identity and Expressive Forms. In International Encyclopedia of the Social and Behavioral Sciences, ed. NJ Smelser and PB Baltes, 2212-2219. Oxford: Elsevier Science.

SPS. 2005. Segunda Jornada del Festival: Inauguración del Mukkayem Tradicional. Rabouni, Tindouf, Algeria. Accessed 29 Apr 2006.

SPS. 2006. Recibimiento Triunfal a Tamek en Assa. Rabouni, Tindouf, Algeria: Assa: Sahara Press Service. Accessed 29 Apr 2006

SPS. 2007. Acogida Triunfal a los Estudiantes Saharauis en la Universidad Ibn Zohr de Agadir (Marruecos). Agadir: Sahara Press Service. Accessed 14 Feb 2008.

Vandebroek, I, V Reyes-García, UP Albuquerque, R Bussmann, and A Pieroni. 2011. Local knowledge: Who cares? Journal of Ethnobiology and Ethnomedicine 7(35).

Varios, Autores. 2009. La Fuente de Saguia. Relatos de a Generación de la Amistad Saharaui. Zaragoza: Imprenta Provincial de Zaragoza.

Volpato, G, and R Puri. 2014. Dormancy and Revitalization: The Fate of Ethnobotanical Knowledge of Camel Forage Among Sahrawi Nomads and Refugees of Western Sahara. Accepted: Ethnobotany Research \& Applications

Volpato, G, and D Rossi. 2014. Badiya: Los Nómadas Saharauis del Sáhara Occidental, ed. Smashwords. http://www.smashwords.com/books/view/433218.

Volpato, G, and A Waldstein. 2014. Eghindi among Sahrawi refugees of Western Sahara. Med Anthropol: Cross-Cultural Studies in Health and Illness 33(2): 160-177.

Volpato, G, P Kourková, and V Zelený. 2012. Healing war wounds and perfuming exile: the use of vegetal, animal, and mineral products for perfumes, cosmetics, and skin healing among Sahrawi refugees of Western Sahara. Journal of Ethnobiology and Ethnomedicine 8(49): 1-19.

Volpato, G, A Di Nardo, D Rossi, SM Lamin Saleh, and A Broglia. 2013a. 'Everybody knows', but the rest of the world: the case of a caterpillar-borne reproductive loss syndrome in dromedary camels observed by Sahrawi pastoralists of Western Sahara. Journal of Ethnobiology and Ethnomedicine 9(5).

Volpato, G, D Rossi, and D Dentoni. 2013b. A reward for patience and suffering Ethnomycology and commodification of desert truffles among Sahrawi refugees and nomads of Western Sahara. Economic Botany 67(2): 147-160.

Wallerstein, I. 1987. The construction of peoplehood: racism, nationalism, ethnicity. Sociological Forum 2(2): 373-388.

Wilson, A. 2012. Households and the production of public and private domains: revolutionary changes in Western Sahara's liberation movement. Paideuma 58: $19-43$

Ziker, JP. 2006. The social movement of meat in Taimyr, Northern Russia. Nomadic Peoples 10(2): 105-122.

doi:10.1186/s13570-014-0007-4

Cite this article as: Volpato and Howard: The material and cultural recovery of camels and camel husbandry among Sahrawi refugees of Western Sahara. Pastoralism: Research, Policy and Practice 2014 4:7.

\section{Submit your manuscript to a SpringerOpen ${ }^{\circ}$ journal and benefit from:}

- Convenient online submission

- Rigorous peer review

- Immediate publication on acceptance

- Open access: articles freely available online

- High visibility within the field

- Retaining the copyright to your article

Submit your next manuscript at $>$ springeropen.com 